\title{
REKONSTRUKSI PEMAHAMAN HADIS
}

\author{
(Analisis terhadap Cakupan Hadis dalam Fatwa MUI tentang \\ Kesetaraan Gender) \\ Mohammad Nawir \\ Pascasarjana Universitas Islam Negeri (UIN) Syarif Hidayatullah \\ Jakarta
}

\begin{abstract}
The study concluded that the hadiths about gender equality in the fatwas of the Indonesian Ulama Council (MUI) was based on the validity of the arguments hadith, such as the rules of a tradition validity, which has been tested and recognized by the Hadith scholar of classical and authoritative. This study agrees with Ibnuddin (2011) which states that the MUI in the case of interfaith marriage less open to the socio cultural and socio real political currently there in the country, resulting in a controversial fatwa. M. Quraish Shihab (2003), Yusuf al-Qaradawi (2011), which explains that to understand the traditions of the creation of women, needs to be understood metaphorically. This study differs from Asrorun Ni'am Salah M. (2012) which states that the MUI fatwa on female circumcision is neutral between the two groups. The first group stated to perform the practice of circumcision in excess and the second group who forced himself to prohibition against female circumcision absolutely. Yunahar Ilyas (1997) study which states that the hadith about the creation of woman from the rib is a sound hadith that already valid either in text or contextmeaning. This study uses the Socio-historical approach. The primary data is a collection of MUI
\end{abstract}


fatwa on gender equality issues, among them the fatwa of the imam pray for women, female circumcision, interfaith marriage, female leader. While secondary sources are books of hadith, hadith and sirah Sharh al-Nabawiyah especially that rested in the MUI issued fatwa

Keywords: MUI, Understanding Hadith, gender equality.

Penelitian ini menyimpulkan bahwa hadis-hadis tentang kesetaraan jender dalam fatwa-fatwa Majelis Ulama Indonesia didasarkan pada argumen validitas hadis, berupa kaidah-kaidah kesahihan sebuah hadis, yang telah diuji dan diakui oleh ulama hadis klasik dan otoritatif. Penelitian ini sependapat dengan Ibnuddin (2011) yang menyatakan bahwa MUI dalam kasus pernikahan beda agama kurang terbuka terhadap kondisi sosio kultural maupun sosio politik yang saat ini riil ada di Negara ini, sehingga menghasilkan fatwa yang kontroversial. Dan M. Quraish Shihab (2003), Yusuf al-Qaradawi (2011), yang menjelaskan bahwa dalam memahami hadis tentang penciptaan perempuan perlu pahami secara metaforik.Penelitian ini berbeda dengan $\mathrm{M}$. Asrorun Ni'am Soleh (2012) yang menyatakan bahwa Fatwa MUI tentang khitan perempuan bersifat netral antara dua kelompok. Kelompok pertama yang melakukan praktek khitan secara berlebihan dan kelompok kedua yang memaksakan diri untuk melakukan pelarangan khitan terhadap perempuan secara mutlak. Dan Yunahar Ilyas (1997) yang menyatakan bahwa hadis tentang penciptaan perempuan dari tulang rusuk merupak hadis sahih yang sudah tidak dapat diganggu gugat lagi baik makna secara teks maupun konteksnya. Penelitian ini menggunakan Pendekatan Sosio- 
historis. Data primer penelitian ini adalah kumpulan fatwa MUI tentang persoalan kesetaraan gender, di antaranya adalah fatwa tentang imam salat bagi perempuan, khitan perempuan, nikah bedaagama, Pemimpin perempuan. Sedangkan sumber sekunder adalah kitab-kitab hadis, sharh hadis dan sirah alNabawiyah terutama yang menjadi sandaran MUI dalam berfatwa.

Kata Kunci: MUI, Pemahaman Hadis, Kesetaraan gender.

\section{PENDAHULUAN}

Yusuf al-Qardawi pernah mengungkapkan bahwa: "Syariat yang tertuang dalam al-Qur'an dan Sunnah merupakan dua pilar kekuatan umat dan agama Islam merupakan suatu cara hidup dan tata sosial yang memiliki hubungan integral, utuh menyeluruh dengan kehidupan, sehingga idealnya Islam ini tergambar dalam dinamika hukum Islam yang merupakan suatu hukum yang serba mencakup".

Mayoritas umat Islam Indonesia mengakui keberadaan dan kedudukan hadis Nabi sebagai sumber kedua setelah al-Qur'an. Sehubungan dengan ini, para pembaharu generasi pertama telah mengembangkan kajian hadis sejak paruh abad ke 17, yang secara bertahap meningkat dan lebih komprehensif. Hal ini sebagaimana diindikasikan oleh Azumardi Azra, bahwa pembaharuan Islam yang dimulai sejak paruh kedua Abad ke-17 salah satunya dipengaruhi oleh jaringan ulama kosmopolitan yang berpusat di Mekah dan Madinah, yang secara intelektual mereka mengembangkan dua wacana dominan, yaitu hadis dan tarekat. Melalui telaah-telaah hadis, para guru dan murid-murid dalam jaringan ulama tersebut menjadi terhubung satu sama lain. Lebih dari itu, para ulama

${ }^{1}$ Yusuf al-Qardawi. Kayfa Nata'amal ma'a al-Sunnah al-Nabawiyah. (alMansurah:Dar al-Wafa'1990) 
mengambil dari telaah-telaah hadis, inspirasi, serta wawasan mengenai cara memimpin masyarakat muslim menuju rekonstruksi sosio-moral. $^{2}$

Di Indonesia sendiri, pergulatan hadis dengan realitas permasalahan sosial dapat ditelusuri dari keberadaan fatwa-fatwa dari ormas Islam termasuk MUI. Sebuah fatwa dikeluarka karena adanya suatu perkara akibat perkembangan sosial yang dihadapi oleh umat. Karena itu, fatwa mensyaratkan adanya orang yang meminta atau kondisi yang memerlukan adanya pandangan atau keputusan hukum. Dengan demikian, fatwa tidak persis sama dengan tanya jawab keagamaan biasa seperti dalam pengajianpengajian. Bukan juga sekedar ceramah-ceramah seputar satu ajaran agama. Fatwa senantiasa sangat sosiologis. Ia mengandung adanya perkembangan baru, persoalan baru, atau belum jelas duduk masalahnya. ${ }^{3}$

Fatwa-fatwa yang dikeluarkan oleh otoritas-otoritas keagamaan memberikan kepada kita bagaimana sesungguhnya teks yang berasal dari masa lampau itu dimaknai dalam konteks kekinian dalam realitas yang baru. Bila di analisis lebih lanjut di dalam fatwa tersirat adanya satu usaha untuk mengaktualisasikan nilai-nilai keislaman masa klasik kepada masa sekarang. Salah satunya dapat dilihat dalam fatwa yang dikeluarkan oleh MUI pada tahun 2005 tentang imam perempuan dalam salat. ${ }^{4}$

Ada beberapa permasalahan seputar perempuan yang sering menjadi polemik khususnya di kalangan intelektual muslim di antaranya kedudukan perempuan dalam kepemimpinan politik dan rumah tangga, pernikahan perempuan muslim terhadap laki-laki non muslim, khitan perempuan, imam perempuan dalam salat jamaah

2 Azumardi Azra, Jaringan Ulama Timur Tengah dan kepulauan Nusantara Abad XVII dan XVIII: Melacak Akar-akar Pembaharuan Pemikiran Islam di Indonesia (Bandung: Mizan, 1998), 294-296.

${ }^{3}$ Quraish Shihab, Era Baru Fatwa Baru, pengantar (Jakarta: Teraju, 2003), 16.

4 Lihat "Fatwa Majelis Ulama Indonesia" Nomor: 9/MUNAS VII/MUI/13/2005 tentang Wanita Menjadi Imam Shalat, 240. 
yang makmumnya terdapat laki-laki, ketaaatan seorang istri terhadap suami dll.

\section{METODE}

Penulis menggunakan pendekatan sosio-historis. ${ }^{5}$ Karena penelitian ini berkaitan erat dengan sosio historis sebuah hadis. Sehingga dengan menggunakan pendekatan tersebut, maka diharapkan akan menemukan data-data yang viled berkaitan dengan sejarah dan keadaan perempuan pada saat hadis tersebut muncul. Demi mendapatkan kesimpulan yang mendalam dan komprehensif,penelitian ini tidak cukup hanya dengan dua pendekatan secara umum seperti yangtelah dipaparkan di atas. Penelitian ini membutuhkan landasan teori sebagai tolakukur. Setidaknya ada dua landasan teori yang digunakandalam penelitian ini. Pertama, teori Feminis Liberal milik Margaret Fulleryang menjelaskan bahwa semua manusia, laki-laki dan perempuan, diciptakan seimbang dan serasi dan semestinya tidak terjadi penindasan antara satu dengan yang lainnya. Kedua, teori mayor dan minor milik Syuhudi Ismail yang menjelaskan bahwa kesahihan sanad dan matan hadis mestinya bergandengan, tidak terjadi kepincangan satu dengan yang lainnya. Dan memahami hadis nabi dengan mengelompokkan secara temporal, lokal, dan universal. ${ }^{6}$ Pendekatan ini dibutuhkan untuk menganalisis keautentikan dan relevansi hadis-hadis yang digunakan oleh MUI sebagai sandaran hukum dalam persoalan perempuan dan kesetaraan jender.

Penelitian ini juga menggunakan beberapa metode dan pendekatan ilmu hadis dalam memahami hadis Nabi saw. ada beberapa istilah yang sering digunakan dalam ilmu hadis, yaitu: sharh al-hadith, fiqh al-hadith dan fahm al-hadith. Perbedaanketiga metode ini dalam memahami hadis Nabi harus diketahui secara jelas, agar tidak menimbulkan kerancuan dalam melakukan penelitian atau memahami suatu teks hadis.

\footnotetext{
${ }^{5}$ Peter Connoly, Aneka Pendekatan Studi Agama (Yogyakarta: LKIS Yokyakarta, 2002), 267.

${ }^{6}$ Syuhudi Ismail, Hadis Nabi Yang Tekstual dan Kontekstual, (Jakarta: Bulan Bintang, 2009), 3-7.
} 


\section{a. Sharh al-Hadith}

Sharh al-Hadith yaitu menjelaskan atau mengungkap makna hadis(al-idah wa al-bayan li al-hadith) yang sering digunakan untuk menyebut komentar terhadap hadis yang tertulis dalam teks (matn). Kata sharh tidak hanya digunakan dalam hadis, tetapi juga dalam disiplin ilmu yang lain, seperti tauhid, tasawuf, fikih dan lain- lain. Jikalau dilihat dari segi keluasan cakupannya, sharh hampir sama dengan tafsir dalam disiplin ilmu al-Qur'an. Perbedaannya hanya saja tafsir lebih dikhususkan untuk memahami al-Qur'an, sedangkan sharh bisa digunakan untuk disiplin ilmu yang lain. Dengan demikian, ketentuan umum sharh adalah sebagai penjelasan terhadap teks tertentu, baik teks hadis, fikih, ungkapan sya'ir dan sebagainya. ${ }^{7}$ Dalam kaitannya dengan disiplin ilmu- ilmu tersebut, sharh memiliki beragam bentuk, seperti hasyi'ah, yaitu upaya menjelaskan teks dengan melampirkan penjelasannya di sekeliling teks yang disyarahkan. Ada pula yang berbentuk mamjuz, yaitu upaya menjelaskan teks dengan menggabung antara teks dengan penjelasannya. Pembeda antara teks dan sharh, bisa diketahui dengan penggunaan penulisan cetak tebal dan diberi tanda dalam kurung untuk teks. Bentuk lainnya adalah ta'liq, yaitu sharh yang peletakannya terpisah dengan teks atau matannya. ta'liq ini bisanya hanya digunakan untuk komentar terhadap hal-hal yang penting saja dari teks atau matan dalam bentuk nomor atau tanda lainnya. Dalam kaitannya dengan sharh al-hadith, ia merupakan pemahaman hadis Nabi saw. yang paling tua dan paling mapan. Ada banyak teori yang sudah berkembang dalam metodologi sharh al-hadith, yaitu tahlili (analisis), ijmali (global), muaqarin (komparasi). Penjelasan ketiga metode ini adalah sebagai berikut:

\section{Metode Tahlili}

Metode tahlili adalah metode yang menjelaskan hadis-hadis Nabi saw. dengan memaparkan segala aspek yang terkandung dalam hadis tersebut serta menerangkan makna-makna yang tercakup di dalamnya sesuai dengan kecendrungan dan keahlian pen-sharh dan

${ }^{7}$ Muhammad Baqir al-Majlisy, Bihar al-Anwar al-Jami'ah Lidurori Akhbari al-A 'imaat al-Athar(Libanon: Mu'asasah al-Wafa'). Juz 1, 26. 
sharhnya dapat berbentuk ma'thur atau ra'yi. Pen-sharh memulai penjelasannya dari kalimat demi kalimat, hadis demi hadis secara berurutan. Uraian tersebut menyangkut berbagai aspek yang dikandung hadis seperti kosakata, konotasi kalimatnya, latar belakang turunnya hadis (jika ditemukan), kaitannya dengan hadis lain, dan pendapat-pendapat yang beredar di sekitar pemahaman hadis tersebut, baik yang berasal dari sahabat, para tabi'in maupun para ulama hadis. metode tahlili adalah sebagai berikut : 1) Menjelaskan makna dalam hadis secara berurutan, 2) Menerangkan asbab al-wurud al-hadith (jika ada). ${ }^{8}$

2. Metode Ijmali (global)

Metode ijmali (global) adalah metode yang menjelaskan atau menerangkan hadis-hadis sesuai dengan urutan dalam kitab hadis yang ada dalam kitab hadis secara ringkas, tapi dapat merepresentasikan makna literal hadis dengan bahasa yang mudah dimengerti dan dipahami. 1) pen-sharh langsung melakukan penjelasan hadis dari awal sampai akhir tanpa perbandingan dan penetapan judul. Penjelasan umum dan sangat ringkas, 2) pen-sharh tidak memiliki ruang untuk mengemukakan pendapat sebanyakbanyaknya. Namun demikian, penjelasan terhadap hadis-hadis tertentu juga diberikan agak luas, tetapi tidak seluas metode tahlili.

3. Metode Muqarin (Komparasi)

Metode muqārin adalah metode yang memahami hadis dengan beberapa cara:

pertama, membandingkan hadis yang memiliki redaksi yang sama atau mirip dalam kasus yang sama atau memiliki redaksi yang berbeda dalam kasus yang sama. kedua, membandingkan berbagai pendapat ulamasharh dalam men-sharh hadis. Jadi, dalam memahami hadis metode ini tidak hanya membandingkan hadis dengan hadis yang lain, tetapi juga membandingkan pendapat para ulama (pen-syarh) dalam men-syarh hadis.

\section{b. Fiqh al-Hadith}

${ }^{8}$ Muhammad Baqir al-Majlisy, Bihar al-Anwar al-Jami'ah Lidurori Akhbari al-A 'imat al-Athar(Libanon: Mu'asasah al-Wafa'). Juz II, 35. 
Fiqh al-hadith adalah memahami atau mengusai maksud hadis Nabi saw. (ihatah li al-hadith). Sedangkan secara terminologi dapat diartikan dengan upaya mengambil kesimpulan (istinbat) inti atau tema yang terkandung dalam hadis Nabi saw. Dengan demikian, dapat dipahami bahwa fiqh al-hadith hanya berupaya memahami hadis Nabi saw. dari aspek tujuan atau tema utama bahasan hadis tanpa menyinggung bahasan tentang sanad, perawi, mukharrij dan hal lainnya yang tidak berhubungan dengan maksud hadis. Dapat diambil kesimpulan bahwa istilah fiqh al-hadith memang hanya ditekankan pada upaya memahami hadis Nabi saw. dengan mengeluarkan simpulan dari hadis itu tanpa menyinggung masalah riwayat hadis.

\section{c. Fahm al-hadith.}

Istilah fahm al-hadith lahir jauh lebih belakangan dari syarh al-hadith. Ia merupakan istilsah yang lahir di abad modern oleh ulama-ulama hadiskontemporer. Muhammad bin Abd al-Razzāq Aswad menyebutkan bahwa istilah fahm al-hadith ini muncul belakangan ketika para ulama berupaya memahami hadis Nabi saw. dengan menyesuaikan kondisi keadaan masyarakat sekarang. Istilah fahm al-hadith ini banyak ditemukan di kitab-kitab tulisan Muhammad al- Ghazālī, Yūsuf al-Qardhāwī dan ulama- ulama hadis Timur Tengah lainnya. Muhammad al-Iwaji menjelaskan bahwa fahm al-hadith adalah istilah umum yang meliputi seluruh upaya pemahaman terhadap hadis Nabi saw. Menurutnya, fahm al-hadith ini mencakup sharh al-hadith, dan fiqh al-hadith. Ia bukan merupakan teori, tetapi hanya istilah yang diungkapkan untuk upaya memahami hadis Nabi saw. Pernyataan ini dibantah oleh Muhammad bin Abd al-Razzaq Aswad. Menurutnya, fahm al-hadith merupakan salah satu dari teori-teori dalam upaya memahami hadis Nabi saw., hanya saja teori ini memang belum mapan dan pasti.

Berdasarkan fakta sejarah yang membuktikan adanya fungsi Nabi Muhammad saw. selain sebagai Rasul yang bertugas 
menjalankan fungsi risalah kenabian, ${ }^{9}$ beliau juga sekaligus berfungsi sebagai pemimpin masyarakat, kepala negara, panglima perang, hakim dan juga sebagai manusia biasa. ${ }^{10}$ Berkaitan dengan status Nabi saw, maka mengkaji hadis dengan melihat status Nabi saw. dan konteks sebuah hadis pada saat sebuah hadis disabdakan serta mengetahui bentuk-bentuk matan hadis merupakan upaya yang sangat penting dalam menangkap makna hadis secara utuh. Oleh sebab itu, beberapa pendekatan seperti pendekatan historis, sosiologis, sosio-historis, antropologis, dan psikologis dalam pemahaman hadis sangat diperlukan dalam kerangka menemukan keutuhan makna hadis dan mencapai kesempurnaan kandungan maknanya. $^{11}$

\section{HADIS TENTANG HUKUM IMAM PEREMPUAN BAGI JAMAAH LAKI-LAKI DALAM FATWA MUI}

Ditetapkan di Jakarta pada tanggal 21 Jumadil Akhir 1426 H. 28 Juli 2005 M. Pimpinan sidang komisi C bidang fatwa yang diketuai oleh K.H. Ma'ruf Amin, sekretaris Drs. H. Hasanuddin, M.Ag.

Fatwa MUI ini, pada dasarnya hanya mempertegas hukum tentang imam perempuan dalam salat. Karena di kalangan ulama terdahulu telah dibicarakan panjang lebar mengenai hal ini, keputusan yang diperoleh pun dalam musyawarah nasional MUI VII, pada 19-22 jumadil akhir 1426 H. / 26-29 juli $2005 \mathrm{M}$ adalah persis dengan pendapat imam Syafi'i dan Ahmad Ibn Hanbal. ${ }^{12}$

Fatwa ini, merupakan tanggapan MUI terhadap fenomena yang mengejutkan di salah satu daerah bagian Amerika Serikat

9 Mahmud Shaltut, al-Islam 'Aqidah wa al-Shari'ah (Cairo: Dar alQalam, 1966), 510.

${ }^{10}$ Karen Amstrong, Sejarah Tuhan, (Cet. ke-2; Bandung: Mizan, 2007), 215-220.

${ }^{11}$ Syuhudi Ismail, Hadis Nabi Yang Tekstual dan Kontekstual, (Jakarta: Bulan Bintang, 2009), 33.

${ }^{12}$ Hasan Sulayman al-NuIr dan Alwi 'Abbas al-Maliki, Ibanat al-Ahkam Sharh Bulug al-Maram (Beirut: Dar al-Thaqafah al-Islamiyah, 1960), II, 41. 
pada tahu 2005. Seorang perempuan yang bernama Aminah Wadud Muhsen mengambil peran yang selama ini hanya dilakukan oleh seorang laki-laki. Dia berusaha melakukan sebuah dekonstruksi pemahaman klasik seputar persoalan kesetaraan antara laki-laki dan perempuan. lalu kemudian pemahamannya tersebut disusul dengan tindakan yang menurut dia dapat dicontohi. Namun menurut seorang reporter yang sempat hadir pada saat itu, Aminah Wadud ditunjuk oleh para jamaah agar mengambil peran sebagai khatib jum'at dan sekaligus menjadi imam salat. Meskipun ada beberapa reporter lain yang kemudian protes dengan tindakan tersebut. Suasana sempat ricuh lalu kemudian Susan kembali senyap setelah diamankan oleh petugas.

\section{Aspek Hadis}

Di dalam berbagai kitab karya para ulama, memberikan banyak kriteria dan syarat untuk menjadi seorang imam salat. Wahba Zuhaili dalam kitabnya al-fiqh al-islami setidaknya menyebut 12 syarat. ${ }^{13}$ Salah satu persyaratan itu adalah laki-laki jika makmumnya laki-laki atau banci dan tidak sah jika perempuan atau banci mengimami laki-laki dalam salat. Kepercayaan semacam ini merupakan keyakinan secara umum di kalangan umat Islam, khususnya sunni. ${ }^{14}$ Mereka berusaha menunjukkan berbagai dalil untuk mendukung pemikirannya. Permasalahan akan muncul jika kenyataan tersebut terbalik, pada satu saat terjadi seseorang perempuan menjadi imam salat lakilaki. Akankah hal tersebut dapat dibenarkan dalam kacamata syariat? Padahal dalam ibadah berlaku kaidah: الأصل في العبادة التحريم حتى يدل الدليل على الإباحة

Permasalahan tersebut dapat ditemukan jawabannya dalam hadis. Majelis Ulama Indonesia dalam fatwanya mengungkap 7 butir hadis yang berkaitan dengan persoalan imam

${ }^{13}$ Wabah al-Zuhayli, al-Fiqh al-Islami wa adillatuhu (Beirut: Dar, 1996), Juz II, 174-182.

${ }^{14}$ Wahbah al-Zuhaili, al-fiqh al-Islamī wa Adillatuhu (Beirut: Dar alFikr, 1996), II, 173. 
perempuan terhadap makmum laki-laki. Di antaranya 6 butir hadis yang mengecam posisi perempuan sebagai imam dan hanya satu hadis yang membolehkan yang diriwayatkan oleh Ummu Waraqah. Meskipun MUI mencantumkan salah satu riwayat yang membolehkan imam salat bagi perempuan, namun hadis tersebut tidak menjadi pertimbangan untuk membolehkan seorang perempuan untuk menjadi imam salat bagi laki-laki karena banyaknya hadis-hadis lain yang menyokong posisi perempuan sebagai makmum.

Hemat penulis, hadis yang disandarkan pada Ummu Waraqah perlu dipertimbangkan kembali dengan menelusuri jalur periwayatan sanad dan matannya. Di dalam hadis tersebut terdapat kata-kata ان تؤم اهل دارها secara harfiah perempuan dimungkinkan mengambil posisi sebagai imam salat.

Setelah dilakukan penelusuran melalui metode takhrij alhadith dalam mu'jam mufahras li al-fadhi al-hadith, melalui kata taummu, hadis tersebut, ditemukan di dalam kitab sunan Abu Daud di bab salat dan Musnad Ahmad Ibn Hanbal jilid VI halaman 405. Penelusuran juga dilakukan lewat topik hadis dengan tema hadis Imamah mar'ah melalui kitab Miftah Kunuz al-Sunnah.

1. Sunan Abu Dadu

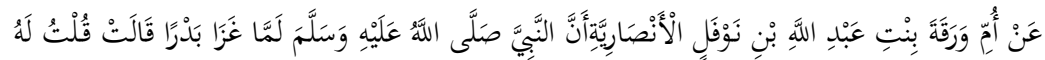

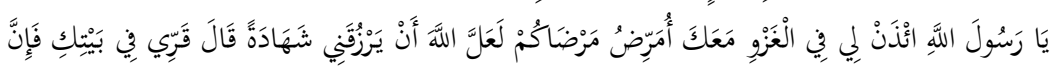

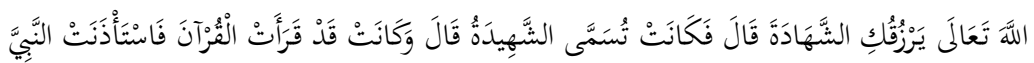

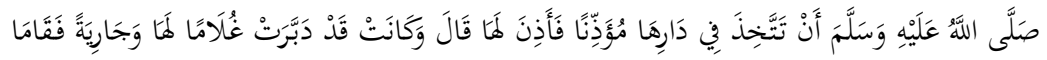

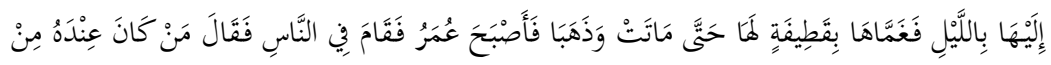

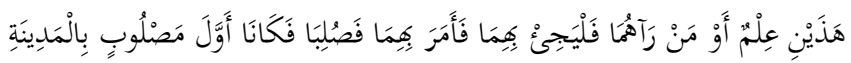

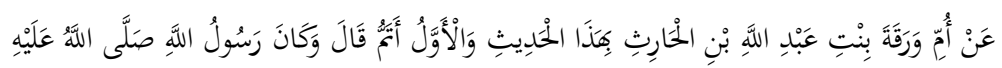

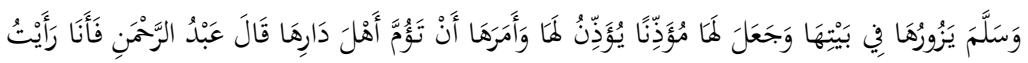

$$
\begin{aligned}
& \text { مُؤَذِنَهَها شَيْخَا كُبِيرًا }
\end{aligned}
$$


2. Musnad Ahmad bin Hanbal

Adapun bunyi teks-teks hadis lainnya terdapat di beberapa kitab: ${ }^{15}$

1. Hadis Riwayat hakim

2. Hadis riwayat al-baihaqi

3. Hadis Riwayat al-Daruqutni

4. Hadis Riwayat Khuzaimah

5. Hadis Riwayat Abu Shaibah

6. Hadis Riwayat Ishaq Ibn Rawahiyah

Berdasarkan penelusuran yang telah dilakukan baik dari segi sanad maupun matan hadis yang diriwayatkan oleh Ummu Waraqah melalu jalur Abu Daud, maka kualitas hadis tentang kepemimpinan perempuan dalam salat sahih dari segi sanadnya dan maqbul dari segi matannya.Meskipun hadis Ummu Waraqah di atas tidak diragukan kualitas kesahihannya, namun beberapa ulama berusaha memberikan interpretasi yang hakikatnya membatasi otoritas perempuan sebagai imam bagi laki-laki. Ibnu Qudamah, yang terkenal dengan sebutan syeikhnya para pengikut Hanbali, dalam al-Mughni, menjelaskan penafsirannya atas hadis tersebut. Pertama. Ummu Waraqah diizinkan Nabi untuk mengimami jamaah perempuan. Hal ini, misalnya diperkuat oleh hadis riwayat Daraquthni. Kedua, kalaupun di antara jamaahnya ada laki-laki, maka sesungguhnya peristiwa ini berkaitan dengan salat sunnah karena sebagian dari fuqaha mazhab Hanbali memang membolehkan perempuan menjadi imam dalam shalat tarawih. Ketiga, apabila kisah Ummu Waraqah benar-benar berkaitan dengan shalat wajib, maka ketentuan itu harus dimaknai bersifat kasuistik dan khusus untuk Ummu Waraqah, sebab ketentuan tersebut tidak pernah disyari'atkan kepada

${ }^{15}$ Program CD, Mausu'ah al-Hadis Syarif, Sunan al-Bayhaqi, no hadis 5136. Sunan al-Dar al-Qutni, bab Salat al-Nisa Jamaah wa Mawqifu Imamihinna, no hadis 1. Mustadrak al-HaJim, bab Salah, no hadis 730. Ibn Huzaymah, no hadis 1676. 
perempuan lain sehingga bermakna khusus untuk keluarga saja. ${ }^{16}$ Atas dasar analisis tersebut, Ibnu Qudamah tetap berkesimpulan bahwa perempuan tidak boleh menjadi imam bagi makmum lakilaki.

Hal lain yang menunjukkan inkonsistensi ulama adalah sikap mereka terhadap hadis Ummu Waraqah. Hadis tersebut dalam berbagai jalurnya telah memenuhi kualifikasi Hadis sahih. Oleh karenanya, ia dapat diterima sebagai hujjah atas kebolehan perempuan menjadi imam laki-laki. Namun, sebagian ulama menolak Hadis ini sebagai dalil, dengan mengajukan Hadis lain yang melarang perempuan menjadi imam laki-laki. Sementara Hadis tersebut, oleh Imam Nawawi dinilai berkualitas da'if. Sebagian ulama lain mengakui keotentikan Hadis tersebut, namun mereka berupaya memberikan interpretasi yang membatasi batasan dan otoritas imam perempuan, seperti tercermin dalam pandangan ibnu Qudamah di atas.

Padahal, kalau dianalisis lebih jauh interpretasi Ibnu Qudamah terhadap Hadis Ummu Waraqah, dapat ditemukan beberapa kelemahan yang mendasar, yang sekaligus dapat menggugurkan analisisnya. Analisis pertamanya bahwa Ummu Waraqah hanya mengimami jamaah perempuan tidak berdasar, sebab tingkat kesahihan Hadis Ummu waraqah yang menyebutkan bahwa di antara makmumnya ada laki-laki, diakui oleh para sarjana hadis. ${ }^{17}$ Analisis keduanya bahwa kebolehan perempuan sebagai imam hanya sebatas pada salat sunah, juga lemah, sebab salat sunah tidak disyari'atkan adanya adzan. Sementara itu, dalam Hadis di atas, jelas-jelas dinyatakan bahwa Nabi menunjuk seseorang mengumandangkan adzan. Lebih-lebih jika posisi imam harus di belakang makmum laki-laki, tentu bukan disebut sebagai imam lagi. Analisis ketiganya bahwa peristiwa Ummu Waraqah bersifat khusus, juga memiliki kelemahan. Jika hanya karena terjadi pada Ummu Waraqah

\footnotetext{
${ }^{16}$ Muhammad bin Qudamah, al-Mughni (Cairo: Dar al-Hadis, t.th), juz I, 413-414.

17 Hamim Ilyas dkk, Perempuan Tertindas "Kajian Hadis-hadis Misoginis"(Jakarta: The Ford Foundation, 2003), 266-267.
} 
sendiri, bukankah banyak peristiwa hukum syari'ah yang diderivasi dari peristiwa tertentu. Dalam kaidah ushuliyah dikenal suatu prinsip bahwa العبرة بعموم اللفظ لا بخصوص السبب)(ketentuan hukum itu diambil dari keumuman lafadz, bukan dari kekhususan sebab). ${ }^{18}$ Namun hal ini dapat pula dimaknai sebagai suatu kebolehan imam perempuan dalam keluarga saja bukan dalam keadaan umum.

\section{Aspek kesetaraan jender}

Keputusan Majelis Ulama Indonesia tentang imam perempuan di dalam salat dengan tegas menolak atas kebolehan perempuan mengambil peran sebagai pemimpin dalam salat. Karena menurut MUI di dalam fatwanya tidak sesuai dengan pendapat ulama, dengan menjadikan al-Qur' an surah al-Nisa ayat 34 dan 6 riwayat hadis yang dipahami oleh MUI sebagai dalil pelarangan perempuan untuk mengambil andil sebagai imam di dalam salat, yang di antaranya makmum laki-laki. Fatwa MUI ini, dengan sangat konsisten mengikut pada pendapat ulama fikih, dengan argumen bahwa kaidah fikih telah menyebutkan • الأصل في العبادة التوفيق والإتباع

Kontroversi seputar boleh tidaknya perempuan sebagai imam telah ada dalam pemikiran-pemikiran ulama terdahulu. Keempat imam mazhab secara tegas menolak imamah perempuan atas laki-laki. Imam Malik dan Abu Hanifah menolak perempuan sebagai imam laki-laki karena imamah merupakan posisi yang terhormat dan agung yang hanya menjadi kewenangan laki-laki. Hal ini berlaku secara mutlak. Sementara itu, Imam Syafi'i dan Ahmad bin Hanbal, membolehkan perempuan menjadi imam terbatas pada sesama perempuan saja. ${ }^{19}$ Diskursus para ulama tentang imamah perempuan mencerminkan keberpihakan mereka kepada kepentingan patriarkhi. Hal ini terlihat dari adanya

\footnotetext{
${ }^{18}$ Nasaruddin Umar, Argumen Kesetaraan gender (Jakarta: Paramadina, 1999), 22

${ }^{19}$ Hasan Sulaiman al-Nur dan Alwi 'abbas al-Malaki, Ibanat al-Ahkam, (Beirut: Dar al-Thaqafah al-Islamiyah, 1909), II, 41.
} 
inkonsistensi rasional dalam pemikiran mereka, di satu sisi dalam persyaratan imam secara umum, pemahaman agama dalam bacaan al-Qur'an dijadikan sebagai kriteria utama. Namun, di sisi lain ketika membahas tentang imamah perempuan, kriteria yang substansial itu justru tidak diterapkan. Penolakan mereka tidak didasarkan pada pertimbangan apakah perempuan memenuhi kualifikasi yang dipersyaratkan, tetapi justru pada "karena ia perempuan". Sementara itu, Abu Tsaur, al-Thabari dan Mazini, merupakan wakil ulama yang membolehkan secara mutlak perempuan sebagai imam. ${ }^{20}$ Namun, pandangan kelompok ini, tidak muncul ke permukaan, bahkan hampir tenggelam dalam diskursus pemikiran Islam. Dalam konteks ini, seperti ditegaskan oleh Ibnu Rusyd bahwa wacana imamah perempuan memang sengaja diredam dalam diskursus pemikiran Islam. ${ }^{21}$

Islam dengan misi pembebasannya yang berpijak pada tauhid harus selalu dihadirkan dalam realitas sosial masyarakatnya sehingga mampu melakukan perubahanperubahan sosial. Qasim Amin, menulis buku yang sangat terkenal berjudul Tahrir al-Mar'ah, menyimpulkan bahwa Islam memberikan posisi yang cukup tinggi kepada perempuan, namun faktor tradisi yang kuat yang berasal dari luar Islam menjadikan perempuan Islam terkebelakang. Bahkan menurutnya umat Islam mengalami kemerosotan karena separo dari umatnya, yaitu perempuan mengalami kemunduran. Maka untuk mendapatkan kembali kejayaan Islam tidak ada jalan lain kecuali memberikan kemerdekaan kepada kaum perempuan. ${ }^{22}$ Dalam konteks ini, Moeslim Abdurrahman mengajukan model tafsir transformatif, yakni model penafsiran yang setidak-tidaknya mencakup tiga wilayah interpretasi: pertama, memahami konstruk sosial; kedua, membawa konstruk sosial itu berhadapan dengan interpretasi teks

\footnotetext{
${ }^{20}$ Muhammad Ibn Isma'il al-San'ani, Subul al-Salam, ditahqiq oleh Abd al-Azīz Hawli, (Beirut: Dar Ihya' al-TuraTh al-'Arabi, 1379), II, 35.

${ }^{21}$ Ibn Rusyd, Bidaayah al-Mujtahid (Oman: Bayt al-Afkar al-Dawliyah, 2007), 175-176.

${ }^{22}$ Qasim Amin, Tahrï al-Mar'ah (Mesir: al-Markaz al-'Arabī li al-Bahth wa al-Nashr, 1948), 98.
} 
(al-Qur'an); dan ketiga, hasil penghadapan konstruk sosial dan model ideal teks itu kemudian diwujudkan dalam aksi sejarah yang baru, yakni transformasi sosial. ${ }^{23}$ Dalam model penafsiran ini, al-Qur'an "dibaca" secara doublehermeneutics. Artinya, ia dihadirkan tidak secara skriptural sebagai petunjuk umat Islam yang hanya berhenti pada tataran wacana, tetapi harus dikonfrontasikan dengan realitas sosial atau direalisasikan pada tataran praksis yang dapat menciptakan perubahan sosial.

Persoalan perempuan atau jender dapat diselesaikan dengan menggunakan pemahaman tafsir transformatif. Dengan berpijak pada realitas sosial yang ada, maka perlu dilakukan analisis terkait dengan konstruksi sosial terhadap persoalan jender. Analisis bahasa sangat diperlukan untuk mengetahui bagaimana bentuk konstruksi sosial terkait dengan perempuan. Hal ini penting, karena realitas sosial' pada dasarnya ada dalam ciptaan bahasa, dalam rekayasa permainan pengucapan yang berbeda-beda (the diversity of genres and language games). ${ }^{24}$ Tentu saja realitas dapat dimanipulasikan melalui permainan bahasa tersebut karena ada hubungan antara pemilihan bahasa yang digunakan untuk merumuskan suatu realitas dengan relasi kekuasaan politik yang ada di balik ungkapan-ungkapan bahasa. ${ }^{25}$ Maka konstruksi sosial tentang perempuan dapat dianalisis melalui bahasa-bahasa yang digunakan untuk mendeskripsikan 2003), 109.

${ }^{23}$ Moeslim Abdurrahman, Islam sebagai Kritik Sosial (Jakarta: Erlangga,

${ }^{24}$ Identifikasi adanya relasi antara realitas dan bahasa, diperkenalkan oleh Ludwig Wittgenstein dengan teori language games dalam bukunya Philosophical Investigation. Untuk keterangan lebih lanjut teori tersebut dan aplikasinya terhadap al-Qur'an, lihat Komaruddin Hidayat, Memahami Bahasa Agama (Jakarta: Paramadina, 1995)

25 Relasi antara bahasa dan kekuasaan, terutama muncul dalam pemikiranpemikiran postrukturalisme dan atau postmodernisme, seperti Michael Foucault, Jacques Derrida, Julia Kristeva, dan lain-lain. Lihat George Ritzer, Teori Sosial Postmodern (Yogyakarta: Kreasi Wacana, 2004). Nyoman Kutha Ratna, Teori, Metode, dan Teknik Penelitian Sastra (Yogyakarta: Pustaka Pelajar, 2006), 143-290. Yasraf Amir Piliang, Hipersemiotika, Tafsir Cultural Studies Atas Matinya Makna (Yogyakarta: Jalasutra, 2003). 
atau mendefinisikan perempuan. Dalam wacana imam perempuan bagi laki-laki, para ulama selalu menggunakan ungkapanungkapan bahasa seperti pembangkit birahi laki-laki, kurang akal, lemah agamanya, untuk mendefinisikan perempuan, yang pada gilirannya tidak memungkinkan perempuan menjadi pemimpin ataupun imam. Definisi ini telah mereduksi totalitas eksisitensi diri perempuan, yang akan berpengaruh terhadap pemaknaan perempuan atas konsep dirinya. Secara lebih luas, implikasi dari pemaknaan ini dapat terlihat dalam realitas sekarang, di mana perempuan cenderung menerima eksploitasi fisiknya dalam berbagai praktek sosial, seperti pornografi, porno aksi, dan sebagainya. ${ }^{26}$

Islam datang membawa berita gembira, termasuk berita gembira kepada kaum perempuan, hal ini tampak pada Semangat kesetaraan laki-laki dan perempuan yang dibawa oleh al-Qurna dan dipraktekkan langsung oleh Nabi, namun pada perkembangan berikutnya tidak populer, karena bertentangan dengan kenyataan riil tradisi Arab patriarkhi yang menguat kembali. Menurut penelitian Reuben Levy seorang yahudi yang mencoba menelusuri fikih dari akar tradisi Arab. Menyimpulkan, bahwa fikih yang bercorak patriarkhi itu adalah pengaruh langsung dari para penafsir ajaran Islam yang pertama. Para penafsir pertama ini umumnya berasal dari Turki dan Persia, di mana tradisi patriarkhi ini sangat kuat. Mereka ini seringkali memaksakan pandangan-pandangannya berdasarkan tradisi mereka ke dalam ajaran-ajaran Islam. Levy juga menemukan, bahwa pemingitan perempuan yang dipandang sebagai suatu keharusan bagi para muslimah itu juga direkayasa oleh para penafsir yang berasal dari Persia, tempat di mana para perempuan sudah lama dikurung di rumah. $^{27}$

\footnotetext{
${ }^{26}$ Yasraf Amir Piliang,Dunia yang Dilipat: Tamasya Melampaui Batasbatas Kebudayaan (Yogyakarta: Jalasutra, 2004) 339-351.

${ }^{27}$ Reuben Levy, The Sosial Structure of Islam, Terj. H. Ahmad Ludjito: "Susunan Masyarakat Islam" (Jakarta : Pustaka Firdaus, 1986), 139-143.
} 
Konstruksi pemahaman yang diterapkan oleh para penyusun kitab fikih yang kemudian dijadikan sandaran argumen oleh MUI, juga menampilkan pola pikir patriarkhal, yang oleh Karen J. Warren dicirikan sebagai: (1) pola pikir berdasarkan nilai hierarkis, yaitu pola pikir "atas-bawah" yang memberikan nilai, status, atau prestise yang lebih tinggi kepada apa yang "di atas" daripada yang "di bawah"; (2) dualisme nilai, misalnya pasangan yang berbeda yang dipandang sebagai oposisi (dan bukannya melengkapi) dan eksklusif (dan bukannya inklusif), dan menempatkan nilai lebih pada salah satu dari suatu pasangan gagasan daripada yang lain (dualisme yang memberikan nilai atau status yang lebih tinggi kepada apa yang secara historis diidentifikasi sebagai "pikiran", "nalar", dan "laki-laki" daripada apa yang secara historis diidentifikasi sebagai "tubuh", "perasaan", dan "perempuan"); dan (3) logika dominasi, yaitu struktur argumentasi yang menuju kepada pembenaran subordinasi. ${ }^{28}$ Bahasa-bahasa khusus yang diatributkan, dan yang dianggap inheren dalam diri perempuan, mengesankan ketidaksempurnaan perempuan karena adanya beberapa sifat negatif yang hanya dimiliki perempuan. Sementara itu, laki-laki, memiliki kesempurnaan penuh. Ketidaksempurnaan inilah, yang ketika dioposisikan dengan kesempurnaan laki-laki menjadi legitimasi "untuk membuat perempuan tidak layak menjadi pemimpin".

Sebetulnya masih banyak ayat al-Qur'an dan Hadis yang menyingung tentang kesetaraan manusia. Namun dalil yang terdapat dalam surat al-Hujurat ayat 13 cukup mewakili dari dalil-dalil yang lainnya. ${ }^{29}$ Kehadiran gagasan ini telah mendekonstruksi kultur masyarakat Arab yang mengukur kualitas dan kemuliaan seseorang berdasarkan etnisitas, kekayaan, kekuasaan, dan jenis kelamin yang kemudian berimplikasi terhadap manifestasi kultural dan praktik sosial, berupa

\footnotetext{
${ }^{28}$ Rosemarie Putnam Tong, Feminist Thought, Terj. Aquarini Priyatna Prabasmoro, (Yogyakarta \& Bandung: Jalasutra, 2006), 359-360.

${ }^{29}$ Zaitunah Subhan, al-Quran dan Perempuan (Jakarta: Prenadamedia Group, 2015), 20-25.
} 
penindasan, subordinasi, dan eksploitasi kelompok-kelompok yang "tidak mulia", lemah, dan marginal. Akibatnya, dengan adanya legitimasi kultural tersebut, proses dehumanisasi berjalan secara sistematis.

Sebuah teks dapat bermakna secara eksistensial dalam masyarakat jika ia memiliki basis kultural komunitas masyarakat yang melingkupinya. Dalam konteks ini, budaya berperan sebagai produsen teks sehingga realitas-realitas yang tergambar di dalam teks sebagian mencerminkan realitas sosial budaya dari masyarakat yang membentuknya. Sebaliknya, teks juga memiliki peran sebagai produsen budaya. Artinya, teks memiliki efektivitas untuk mempengaruhi dan mengubah budaya yang kemudian direkonstruksi dalam bentuknya yang baru. Hubungan antara teks dan budaya dalam kedua sisinya tersebut di atas bersifat dialektis dan kompleks, tidak bersifat linear dan pasif. ${ }^{30}$

Fatimah Mernissi misalnya seorang yang tumbuh besar di kalangan orang-orang yang subordinatif terhadap perempuan, berpandangan bahwa sebetulnya semangat kesetaraan yang digembor-gemborkan olehnya, bukan hanya didasarkan atas pengaruh dari feminisme Barat. Akan tetapi, pada dasarnya konsep kesetaraan laki-laki dan perempuan tersebut sebenarnya telah tersurat dalam teks agama (wahyu dan sunnah). Hanya, karena peranan otoritas ulama mendominasi penafsiran teks-teks agama, sehingga lebih mengutamakan kepentingan laki-laki dan menjustifikasi atas dominasinya, serta mampu menciptakan masyarakat patriarkhi. Hal semacam inilah yang dimaksudkan oleh Mernissi perlu dikaji kembali dengan menggunakan pendekatan hermeneutik,yaitu sebuah upaya untuk reinterpretasi terhadap teks-teks agama dalam kaitannya relasi antara laki-laki dan perempuan. ${ }^{31}$

Realitas sosial yang merupakan representasi dari teks amat sangat mempengaruhi dalam melakukan pembacaan terhadap

${ }^{30}$ Nasr Hamid Abu Zayd, Mafhum al-Nas, 24-25.

${ }^{31}$ Nur Mukhlis Zakariyah, "Kegelisahan Intelektual Seorang Feminis," (Telaah Pemikiran Fatima Mernissi Tentang Hermeneutika Hadith), KARSA, Vol. 19 No. 2 (Tahun 2011): 127. 
teks. Teks-teks agama ketika dibaca dalam sebuah konteks tertentu, maka amat dipengaruhi oleh pembaca. Begitu juga teks yang merupakan representasi tersebut sebenarnya hanyalah sebuah produk pemikiran para penafsir teks, yang di dalamnya termasuk para ulama, tokoh agama, pendeta, ilmuwan dan lain sebagainya. Oleh karena itu, pembacaan terhadap teks-teks agama yang dijadikan sumber otoritas masyarakat patriarkhi amat berarti bagi pola hubungan antara laki-laki dan perempuan dalam konteks masyarakat kontemporer.

Pada dasarnya Islam sangat menekankan penghormatan dan persamaan manusia, dan kesetaraan jender. Dalam sejumlah teks suci, baik yang bersumber dari al-Qur'an maupun hadis, terdapat penegasan yang gamblang mengenai sistem kesetaraan jenis kelamin, baik dalam asal kejadian, prinsip kemanusiaan, intelektualitas, maupun harkat dan martabat manusia. Nabi Muhammad SAW telah hadir dengan membawa misi yang memberikan kepada kaum Hawa hak-hak otonomi, sebagaimana yang dimiliki kaum Adam. Beliau pada saat yang sama juga berusaha menghapuskan tradisi-tradisi jahiliah yang sangat diskriminatif, bahkan misoginis. ${ }^{32}$

\section{HADIS TENTANG KHITAN PEREMPUAN}

MUI menetapkan, fatwa tentang hukum pelarangan khitan terhadap perempuan. Pertama, status hukum khitan perempuan. 1) Khitan, baik bagi laki-laki maupun perempuan, termasuk fitrah (aturan) dan syiar Islam. 2) Khitan terhadap perempuan adalah makrumah, pelaksanaannya sebagai salah satu bentuk ibadah yang dianjurkan. Kedua, hukum pelarangan khitan terhadap perempuan adalah bertentangan dengan ketentuan syari'ah karena khitan, baik bagi laki-laki maupun perempuan, termasuk fitrah (aturan) dan syiar Islam. Ketiga, batas atau cara khitan

32 Ernita Dewi, "Pemikiran Amina Wadud Tentang Rekonstruksi Penafsiran Berbasis Metode Hermeneutika," Jurnal Substantia Vol. 15, No. 2, (Oktober 2013): 153. 
perempuan dalam pelaksanaannya, khitan terhadap perempuan harus memperhatikan hal-hal sebagai berikut:

1. Khitan perempuan dilakukan cukup dengan hanya menghilangkan selaput (jaldah/colum/praeputium) yang menut upi klitoris.

2. Khitan perempuan tidak boleh dilakukan secara berlebihan, seperti memotong atau melukai klitoris (insisi dan eksisi) yang mengakibatkan dlarar.

Keempat, Rekomendasi, 1) Meminta kepada Pemerintah cq. Departemen Kesehatan untuk menjadikan fatwa ini sebagai acuan dalam penetapan peraturan/regulasi tentang masalah khitan perempuan. 2) Menganjurkan kepada Pemerintah cq. Departemen Kesehatan untuk memberikan penyuluhan dan pelatihan kepada tenaga medis untuk melakukan khitan perempuan sesuai dengan ketentuan fatwa ini.

1. Aspek Hadis

$$
\text { عن أبي المليح بن أسامة عن أبيه أن النبي صلى الله عليه وسلم قال : الختان سنة للرجال مكرمة للنساء (رواه }
$$

Bahwa Nabi saw bersabda: Khitan merupakan sunnah (ketetapan rasul) bagi laki-laki dan makrumah (kemuliaan) bagi perempuan (HR. Ahmad)

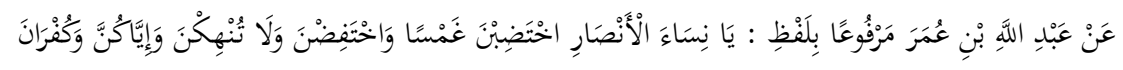

Dari Abdullah ibn Umar bahwa Rasulullah SAW bersabda : "Wahai wanita-wanita Anshor warnailah kuku kalian (dengan pacar dan sejenisnya) dan berkhifadhlah (berkhitanlah) kalian, tetapi janganlah berlebihan". (al-Syaukani dalam Nail al-Author) 


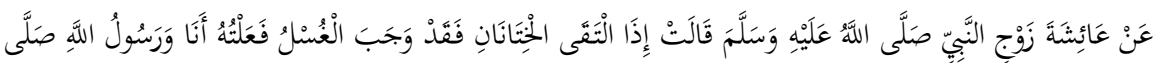

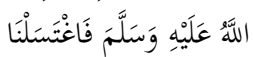

"Apabila bertemu dua khitan maka wajiblah mandi, aku dan Rasulullah telah melakukannya, lalu kami mandi". (HR atTurmudzi, Ibnu Majah dan Imam Ahmad dari isya r.a)

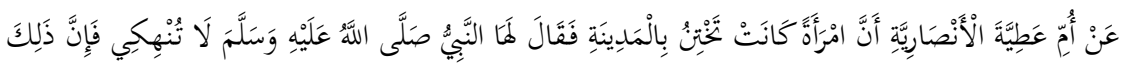

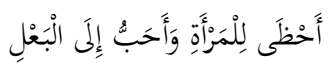

Dari Ummu 'Athiyyah r.a. diceritakan bahwa di Madinah ada seorang perempuan tukang sunat/khitan, lalu Rasulullah SAW bersabda kepada perempuan tersebut: "Jangan berlebihan, sebab yang demikian itu paling membahagiakan perempuan dan paling disukai lelaki (suaminya)". (HR. Abu Daud dari Ummu 'Atiyyah r.a.)

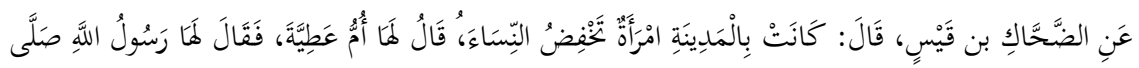

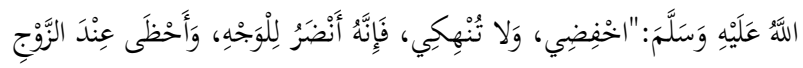

Dari al-Dahhak bin Qais bahwa di Madinah ada seorang ahli khitan wanita yang bernama Ummu 'Athiyyah, Rasulullah SAW bersabda kepadanya: "khifadah (khitanilah) dan jangan berlebihan, sebab itu lebih menceriakan wajah dan lebih menguntungkan suami”. (HR. Thabrani dari al-dahhak)

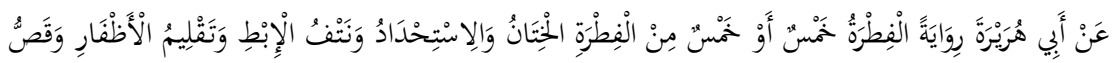

$$
\begin{aligned}
& \text { الشَّارِبِ }
\end{aligned}
$$

"Lima perkara yang merupakan fitrah manusia: khitan, alIstihdad (mencukur rambut pada sekitar kemaluan), mencukur bulu ketiak, menggunting kuku, dan memotong kumis. (HR Jama'ah dari Abu Hurairah r.a.). 
Setelah dilakukan penelusuran, ditemukan beberapa hadis yang berkaitan dengan khitan. Akan tetapi dari semua hadis tersebut, dapat disimpulkan, bahwa hadis-hadis tentang sunat perempuan jikadilihat dari perspektif sanadnya, maka tidak ada yang mencapai derajat hasan atau sahih.Hadis-hadis yang ada justru hanya membolehkan pemotongan sedikit sekali pada bagianprepuce perempuan. Bahkan, ada nada ancaman agar pelaksanaan sunat perempuan tidak sampai membahayakan perempuan. Artinya, kalaupun Islam membolehkan praktek sunat perempuan, maka itu semata-mata demi menghormati tradisi nenek moyang sebelumIslam, yakni tradisi Nabi Ibrahim as. Akan tetapi, pelaksanaannya harus dipastikan tidakmenimbulkan kemudaratan (darar) bagi perempuan.

Penulis juga menelusuri beberapa kitab kanonik, dan hasilnya, seluruh kitab hadis utama atau sering disebut kitab enam (al-kutubal-sittah) tidak memuat hadis-hadis tentang sunat perempuan, kecuali kitab Sunan AbuDawud. Meski begitu, Abu Dawud sendiri mengakui bahwa teks hadis terkait sunatperempuan dalam kitabnya itu berstatus lemah (da'if) dan hadis yang dimaksudkan ituadalah teks hadis dari Ummu Athiyah. ${ }^{33}$

Sayyid sabiq penulis buku fikih sunnah, juga menekankan bahwa semua hadis yang berkaitan dengan perintah khitan perempuan adalah da'if, tidak ada satupun yang sahih. ${ }^{34}$

Melihat kembali kepada sejarah perkembangan tradisi khitan perempuan. Sejarah permulaan khitan perempuan belum ditemukan asal-usul kemunculannya, Asrianti Jamil mengutip dari ahli antropologi, sulit untuk ditemukan awal mula pelaksanaan khitan. ${ }^{35}$ namun yang baru dapat diidentifikasi dari sebuah riwayat, ketika Siti arah (istri pertama) nabi Ibrahim memberikan izin kepada nabi Ibrahim untuk menikahi Siti hajar

\footnotetext{
${ }^{33}$ Ibn al-Athìr, Jami' al-Ushul, juz V. 348, No. hadis 2936.

${ }^{34}$ Sayyid Sabiq, Fiqh al-Sunnah, (Beirut: Dar al-Fikr, 1983), 273.

35 Asrianti Jamil, Kajian Tekstual dan Kontekstual tentang Khitan Perempuan dalam Islam Serta Pelaksanaannya, (Jakarta: Program Pasca Sarjana
} UI 2001), 50. 
kemudian Siti hajar hamil, maka Siti Sarah pun cemburu dan bersumpah akan memotong tiga bagian dari tubuh Siti Hajar. Kemudian nabi Ibrahim menyarankan Siti Sarah untuk melubangi kedua telinga dan mengkhitan kemaluan Siti Hajar. ${ }^{36}$

Dengan menggunakan pendekatan tekstual dan kontekstual yang digagas oleh Syuhudi Ismail, beberapa hadis di atas dapat dipahami sejarah temporal dan lokal (kontekstual). Pada saat itu telah berkembang tradisi khitan di masyarakat Arab, dan belum terjadi mudarat pada perempuan seperti yang terjadi di beberapa daerah bagian Afrika. Maka tidak heran jika di dalam kandungan hadis tersebut disebutkan alasan mengapa nabi melarang kepada Ummi Atiyyah untuk melakukan praktek khitan perempuan secara berlebihan. Karena bisa jadi nabi sudah mengetahui mudaratnya hanya saja hal tersebut masi sangat kental pelaksanaannya maka nabi menuntun secara teknis pelaksanaannya. Berbeda dengan hadis-hadis tentang khitan lakilaki, tidak satupun menyebutkan tuntunan dan batasan yang mesti dikhitan.

Masyarakat di berbagai belahan dunia, termasuk juga masyarakat Islam, telah berupaya menghapuskan berbagai praktek sunat perempuan karena amat membahayakankesehatan tubuh dan juga jiwa perempuan. Bahkan, dalam banyak kasus ditemukan sunatperempuan adalah suatu bentuk upaya menindas dan menghancurkan kemanusiaanperempuan. Sebagai contoh, di negeri Mesir telah ditetapkan undang-undang yangmelarang keras pelaksanaan sunat perempuan. Undang-undang tersebut merujuk padaFatwa Ulama Mesir Tahun 2007 yang melarang pelaksanaan sunat perempuan. Demikianpula di tingkat internasional, PBB melalui Pasal 12 CEDAW (Konvensi PBB tahun 1979tentang penghapusan segala bentuk diskriminasi dan kekerasan terhadap perempuan)secara tegas melarang praktek

${ }^{36}$ Ibn Qayyim al-Jauziyyah, Tuhfah al-Maududi bi Ahkam al-Maudud, terj. Fauzi Bahreisy, Mengantar Balita Menuju Dewasa (Jakarta: Serambi, 2001) 155. 
sunat perempuan dan menganggapnya sebagai bentuk nyatakekerasan terhadap perempuan.

\section{Aspek Kesetaraan Jender}

Majelis Ulama Indonesia (MUI) menetapkan bahwa persoalan khitan perempuan adalah termasuk fitrah (aturan) dan syiar Islam. Khitan terhadap perempuan adalah makrumah, pelaksanaannya sebagai salah satu bentuk ibadah yang dianjurkan. Dalam menetapkan fatwa tentang persoalan khitan perempuan, MUI berpijak pada dalil-dalil syariat (al-Quran, Hadis, dan Qaul al-Ulama), kendatipun demikian, fatwa ini tidak terlepas dari kontroversi utamanya di kalangan pemikir progresif.

Berangkat dari kehawatiran MUI terhadap pengaruh Barat yang liberal yang lepas dari dalil agama yang harus dijadikan pegangan utama. Hal ini disebabkan pandangan yang menyatakan bahwa khitan perempuan melanggar hak asasi manusia (HAM) dan merupakan kejahatan seksual. Pandangan yang melarang khitan perempuan ini membenturkan fikih Islam dengan HAM. Ini merupakan propaganda yang mana hal itu bertentangan dengan pendapat mazhab. Justru yang mesti disosialisasikan adalah tradisi-tradisi yang berkembang sejak lama di masyarakat yang mendukung khitan perempuan.

Sedangkan menurut pandangan sebagian ulama termasuk imam al-Gazali, jika perempuan tidak dikhitan maka akan berdampak pada syahwatnya yang memuncak. Namun jika perempuan dikhitan tidak berlebihan sesuai dengan sabda nabi maka syahwatnya akan stabil dan jika dikhitan dengan cara yang berlebihan maka akan kehilangan syahwatnya.

Setelah diteliti lebih jauh ditemukan bahwa dibalik konsep khitan dengan legitimasi agama, sering terdapat tindakan kekerasan terhadapa perempuan. selain akan berdampak pada berkurangnya kenikmatan seksual juga sewaktu-waktu menyebabkan trauma psikologis. ${ }^{37}$ Menurut Bryk, dengan

37 Asrianti Jamil, Kajian Tekstual dan Kontekstual tentang Khitan Perempuan dalam Islam Serta Pelaksanaannya. Jakarta: Program Pasca Sarjana UI 
dihilangkannya alat perentan libido sexualis, maka daerah erogen berpindah dari muka (klitoris) ke belakang (liang vagina), karena itu rangsangan bagi seorang wanita menjadi berkurang.

Asroru Ni'am di dalam tulisannya menilai bahwa fatwa tentang khitan perempuan ini, berada di posisi yang tengah dari kedua pendapat (sebuah langkah moderasi), ${ }^{38}$ yang melarang secara mutlak dan yang berpendapat bahwa khitan perempuan mesti di potong/dihilangkan, sebagai mana yang diperaktekan di sebagian negara bagian Afrika Utara.

Meski MUI menjelaskan di dalam fatwa bahwa dalam pelaksanaan khitan tidak boleh berlebihan dan mesti dilakukan oleh pihak yang berpengalaman dalam hal itu. Namun tetap saja fatwa ini masih mengandung tanda tanya oleh pihak medis karena tidak didasari dengan bukti-bukti kegunaan dan manfaat dari khitan perempuan, berbeda dengan khitan laki-laki sebagaimana yang dikemukakan oleh Nasaruddin Umar dalam salah satu bukunya, bahwa khitan laki-laki memang sesuai dengan anjuran medis bahwa kulit (kulup) jenis kelamin laki-laki berpotensi menampung penyakit pada kelamin dan dapat mengakibatkan terjadinya pemancaran sperma secara dini (ejaculatio seminis), karena kepala penis yang berkulup lebih sensitif daripada yang tidak berkulup. ${ }^{39}$

Sikap MUI dalam penetapan fatwa tentang khitan perempuan perlu diapresiasi dalam hal eksistensi dan konsistensinya memelihara sesuatu yang dianggap sebagai bagian dari syariat. Namun pada sisi lain juga memungkinkan untuk ditinjau kembali, karena persoalan khitan ini banyak mengundang

2001, 31-32. Lihat juga Jamal Ma'mur, Rezim Jender di NU, 232-235. Maria Ulfa, Muhammadun beserta tim dokter telah melakukan penelitian tentang pelaksanaan khitan di luar Jawa, menyatakan bahwa terdapat beberapa kejadian yang menyebabkan infeksi pada kelamin perempuan. sedangkan Muhammadun menyatakan bahwa terjadi penurunan pada gairah seks perempuan.

${ }^{38}$ Asroru Ni'am, "Fatwa MUI Tentang Khitan Perempuan," Ahkam:Vol. XII, No. 2, Juli 2012. 40

39 Nasaruddin Umar, Ketika Fikih Membela Perempuan (Jakarta: Gramedia, 2014), 66. 
kontroversi dan prakteknya pun berbeda-beda sesuai dengan tradisi yang berkembang di suatu tempat.

Majelis Ulama Indonesia meruppakan kompilasi dari berbagai ulama di seluruh Indonesia, oleh karena itu keilmuannya pun pasti sangat berdimensi dan beragam, akan menjadi aneh jika keputusannya itu masih berkutat pada keilmuan masa lampau meskipun penulis tidak menuntut perubahan sepenuhnya dengan tanpa didasari oleh dalil yang lebih kuat. Dalam hal ini, persoalan khitan perempuan dipandang bagian dari syari'at Islam, padahal belum ditemukan dalil-dalil dari hadis nabi secara khusus menyebutkan hal ini. Hanya saja banyak bertebaran di beberapa literatur-literatur kitab fikih membahas masalah ini, kemudian MUI mengikuti ulama klasik yang telah membahas persoalan ini demi untuk menemukan sebuah legitimasi hukum yang berasaskan pada ulama salaf, yang notabene masyarakat pada saat itu cenderung subordinatif.

Dominasi budaya patriarkhi mencapai puncaknya di abad pertengahan Islam, di mana saat itu penafsiran agama yang diskriminatif dianggap memiliki kebenaran mutlak. Imbasnya segala produk hukum yang dihasilkan para ulama dan imam madzhab abad pertengahan secara seragam tidak memberikan ruang gerak sedikit pun bagi penghargaan terhadap hak perempuan seperti yang tercantum dalam lembaran kitab-kitab kuning. ${ }^{41}$ Dan ironisnya, justru kitab-kitab kuning yang sangat beraroma patriarkhis inilah yang kemudian selama berabad abad menjadi referensi utama dalam masyarakat Islam.

Menurut Khalid, sikap kaum puritan terhadap kaum perempuan yang semata-mata berdasarkan analisis tekstual terhadap sumber-sumber agama mendorong mereka memandang perempuan sebagai sumber kerusakan dan kejahatan sosial serta

\footnotetext{
${ }^{40}$ Fatimah Mernissi dan Riffat Hassan, Setara di Hadapan Allah, Reflasi Laki-laki dan Perempauan dalam Tradisi Islam Pasca Patriarki, 13.

${ }^{41}$ Karen Amstrong, Sejarah Tuhan, (Cet. ke-2; Bandung: Mizan, 2007), 17.
} 
sumber fitnah. ${ }^{42}$ Mereka mengklaim bahwa perempuan akan menjadi penghuni mayoritas neraka dan kebanyakan laki-laki ada di sana karena perempuan. Yang lebih ironis adalah keluarnya fatwa yang menyatakan bahwa perbudakan bukan hanya sah di dalam Islam, tetapi seyogyanya perbudakan itu dilegalkan di Arab Saudi yang berakibat melegitimasi perdagangan ilegal (trafficking) dan eksploitasi seksual dengan pekerja domestik di wilayah teluk, yang lazimnya adalah perempuan dari berbagai negara. ${ }^{43}$

Menurut Khalid, ada satu kata yang merangkum sikap kaum puritan terhadap perempuan, bahwa mereka adalah fitnah yang berarti rayuan seksual, sumber bahaya kerusakan sosial, kekacauan, dan kejahatan. Perempuan dipotret sebagai manusia yang tidak sempurna dan tidak patuh. Mereka tetap berada dalam pengawasan laki-laki, baik dalam kapasitas sebagai anak, istri, maupun anggota masyarakat sehingga mereka tidak pernah menjadi manusia yang independen dan otonom. Kaum perempuan diproyeksikan mengambil peran dengan memenuhi kewajibannya hanya melalui laki-laki. Kaum puritan juga mengumpulkan serangkaian hadis yang merendahkan kaum perempuan, padahal otentitas hadis-hadis tersebut sangat lemah. ${ }^{44}$

Hemat penulis, kelompok yang melarang secara mutlak pelaksanaan khitan tidak berdasarkan pada dalil, sedangkan ada kaidah yang menyatakan bahwa 'adam al-dalil laysa bi al-Dalil. Sedangkan MUI dalam kasus ini, terlalu tergesa-gesa. Sehingga hukum khitan perempuan, yang dapat dijangkau dengan ilmu kedokteran manfaat dan kegunaan pelaksanaannnya, justru mengalami pertentangan.

${ }^{42}$ Abdul Majid, Hermeneutika Hadis Gender (Studi Pemikiran Khaled M. Abou El Fadl dalam Buku Speaking in God's Name; Islamic Law, Authority And Women), Jurnal al-Ulum, Volume. 13 Nomor 2, (Desember 2013), 229-301.

${ }^{43}$ Khalid Abou El Fadl, Selamatkan Islam dari Muslim Puritan, 306-307.

${ }^{44}$ Khalid M. Abou El Fadl, Selamatkan Islam dari Muslim Puritan, 308311. 


\section{HADIS TENTANG PERNIKAHAN BEDA AGAMA}

Majelis Ulama Indonesia, setelah menimbang, mengingat dan memperhatikan. Maka Majelis ulama Indonesia memutuskan dan menetapkan bahwa: 1) Perkawinan beda agama adalah haram dan tidak sah; 2) Perkawinan laki-laki muslim dengan wanita ahli kitab menurut qaul al-mu'tamad adalah haram dan tidak sah. ${ }^{45}$

Keputusan fatwa tersebut didasarkan pada pertimbangan: a) bahwa belakangan ini disinyalir banyak terjadi perkawinan beda agama, b) bahwa perkawinan beda agama ini bukan saja mengandung perdebatan di antara sesama umat Islam, akan tetapi juga mengandung keresahan di tengah-tengah masyarakat, c) bahwa di tengah-tengah masyarakat telah muncul pemikiran yang membenarkan perkawinan beda agama dengan dalih hak asasi manusia dan kemaslahatan, dan, d) bahwa untuk mewujudkan dan memelihara ketenteraman kehidupan berumah tangga. Dalam hal ini dapat disimpulkan bahwa fatwa ini bersifat preventif, ingin melakukan pencegahan dan pertahanan terhadap apa yang menurut MUI sudah menjadi aturan agama sejak dulu. Terlihat dari pijakan MUI yang didasari oleh kehawatiran dan keresahan terhadap fenomena-fenomena yang terjadi di tengah-tengah masyarakat Indonesia khususnya dalam hal pernikahan beda agama. Ditambah lagi dengan berkembangnya pemikiranpemikiran yang mencoba untuk melegalkan pernikahan beda agama dengan alasan Hak Asasi Manusia (HAM) dan perlindungan anak.

Pemikiran tersebut banyak digagas oleh cendekiawan muslim yang pemikirannya bercorak liberal dan inklusif. Suatu contoh, Nur Cholid Majid dan pemuda-pemuda yang mengembangkan pemikirannya berpandangan bahwa persoalan pernikahan laki-laki non muslim dengan perempuan yang beragama Islam merupakan wilayah ijtihadi, dan terikat degan konteks tertentu, di antaranya konteks dakwa Islam saat itu. Di

${ }^{45}$ Majlis Ulama Indonesia, Himpunan Fatwa MUI Sejak 1975 (Jakarta, 2011), 477-481. 
mana jumlah umat Islam saat itu tidak sebesar saat ini, sehingga pernikahan beda agama merupakan sesuatu yang terlarang. Karena kedudukannya merupakan hukum yang terlahir dari proses ijtihad, maka sangat memungkinkan untuk dicetuskan pendapat baru, bahwa perempuan yang beragama Islam boleh menikah dengan laki-laki non muslim, atau pernikahan beda agama secara luas sangat diperbolehkan, apapun agama dan kepercayaannya. $^{46}$

1. Aspek Hadis

$$
\text { تنكح المرأة لمالها ولنسبها وبلمالها ولدينها فاظفر بذات الدين تربت يداك. (متفق عليه عن أبي هريرة) }
$$

Wanita itu (boleh) dinikahi karena empat hal: (1) karena hartanya (2) karena (asal-usul keturunan-nya (3) karena kecantikannya (4) karena agamanya. Maka hendaklah kamu berpegang teguh (dengan perempuan) yang memeluk agama Islam; (jika tidak), akan binasalah kedua tangan-mu. (hadis riwayat muttafaqun alah dari Abu Hurairah r.a)

Majelis Ulama Indonesia hanya melampirkan satu hadis sebagai sandaran hukum tentang persoalan nikah beda agama. Hadis yang digunakan MUI ini, merupakan hadis sahih secara jalur sanad begitu pula dengan matannya, kandungan maknanya pun jelas. Kriteria seorang wanita yang semestinya dinikahi salah satunya adalah pertimbangan agamanya, di dalam hadis tersebut disebutkan bahwa wanita yang memeluk agama Islam. Namun jika diperhatikan lebih jauh, hadis tersebut tidak mengandung makna perintah dengan kata lain keharusan bagi seorang muslim. Melainkan hanya anjuran bagi seorang muslim yang hendak menikah.

Pada sisi lain, di dalam hadis tersebut terdapat kata-kata lidiniha, jika ditarik lebih dalam makna kata tersebut ada sebagian kalangan yang menafsirkan sebagai makna umum yaitu

${ }^{46}$ Nur Cholis Majid, Fikih Lintas Agama : Membangun Masyarakat Yang Inklusif, Pluralis (Jakarta: Paramadina, 2004), 164. 
agamanya yang baik, jadi tidak mesti Islam, yang terpenting adalah berperilaku yang saleh. Dari gagasan tersebut dapat menimbulkan kontroversi maka perlu adanya bandingan terhadap hadis lainnya.

Setelah dilakukan penelusuran tentang makna kandungan hadis tersebut, tidak satupun kitab hadis maupun fikih yang menerangkan secara eksplisit bahwa yang dimaksud dengan din di sini adalah agama Islam dan hanya ditemukan pada kitab ikhtilaf al-Darin wa atharuh fi ahkam al-Shari'ah. Di dalam kitab tersebut dijelaskan bahwa selama perempuan yang dimaksud tidak memendam rasa kebencian terhadap Islam maka hal tersebut diperbolehkan. ${ }^{47}$

Sebetulnya ada beberapa hadis yang membahas tentang pernikahan beda agama, di antara hadis yang terdapat di dalam kitab al-Muwatta, dan shahih al-Bukhari yang menceritakan para muslimah yang kembali ke Mekkah dan suami mereka masih belum masuk Islam kemudian diperintahkan oleh Rasul untuk cerai, dan setelah suami mereka masuk Islam Rasul kemudian menganggap sah pernikahan mereka.

$$
\begin{aligned}
& \text { حدثني مالك عن بن شهاب انه بلغه ان نساء كن في عهد رسول الله صلى الله عليه وسلم يسلمن بأرضهن }
\end{aligned}
$$

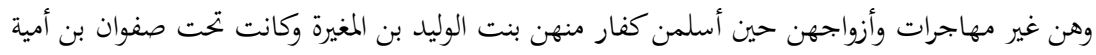

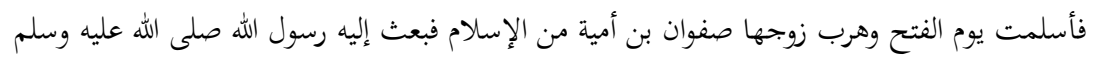

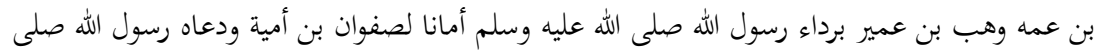

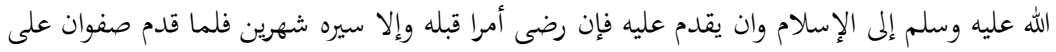

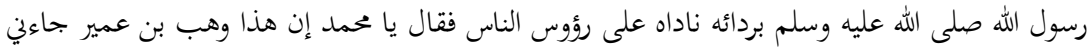

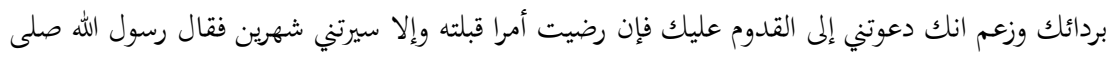

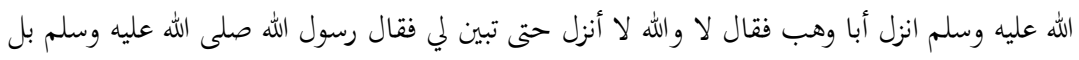

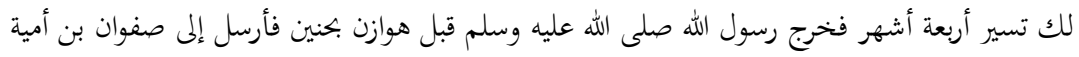

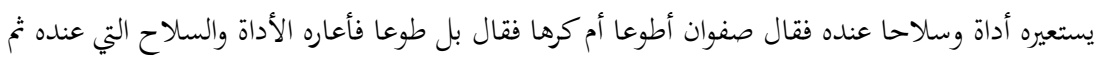

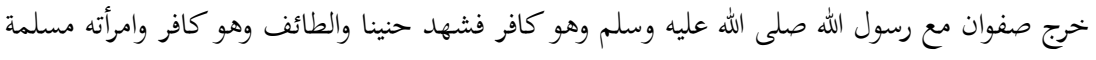

47 Abdul Aziz, ikhtilaf al-Darīn wa atharuh fi ahkam al-Sharì'ah (Madinah Munawwarah: t.p, 2004), 253. 


$$
\text { ولم يفرق رسول الله صلى الله عليه وسلم بينه وبين امرأته حتى اسلم صفوان واستقرت عنده امرأته بذلك }
$$

Kandungan hadis tersebut mengungkap bahwa terdapat wanita-wanita muslimah yang tidak ikut hijrah bersama Nabi SAW dan Kaum Muslim ke Madinah. Mereka menetap di Mekkah bersama para suami yang masih kafir. Di antara mereka adalah putri dari al-Walid ibn al-Mughirah yang bersuamikan Shafwan ibn Umayyah. Kemudian Nabi SAW mengutus putra pamannya, Wahab Ibn 'Umair, dengan membawa selendangnya untuk menemui Shafwan dan mengajaknya masuk Islam. Tetapi ajakan itu ditolak dan Shafwan tetap kafir. Karena itu, ia dipisahkan dari isterinya. Namun, di akhir hadits diketahui bahwa selanjutnya Shafwan memeluk Islam, dan pernikahan antara keduanya pun dipandang sah. Pada catatan kaki yang ada dalam Kitab Muwattha', diketahui bahwa ini derajat hadits ini adalah masyhur. Meski demikian, kemasyhuran hadits ini lebih kuat dari pada sanadnya. ${ }^{48}$

Larangan kawin campur juga dipertegas oleh Imam Bukhari, bahkan ia membuat bab khusus dalam sahihnya: $B a b$ Idza Aslamat al-Musyrikatuawal-NashraniyyahTahtaalDzimmyawal-Harby. Imam Bukhari meriwayatkan dari Ibnu 'Abbas, "jika ada wanita Nashrani lebih dulu masuk Islam dari suaminya, satu saat saja, maka wanita tersebut diharamkan baginya (bagi suaminya)". 49

Hadis yang terdapat di dalam al-Muatta, justru lebih menekankan secara eksplisit larangan pernikahan beda agama (pernikahan seorang Muslimah dengan seorang kafir), akan tetapi MUI tidak melampirkan di dalam fatwanya. Hal ini mengindikasikan bahwa perempuan sudah distigmasi oleh MUI

\footnotetext{
${ }^{48}$ Malik Ibn Anas, Al-Muwattha'. Jilid II. (Beirut: Dar Ihya' al-Turath al'Arabìi. Cet. I, 1424/2003), II, 52.

${ }^{49}$ Al-Bukhâri. 1400 H. Jami' al-Shahih. Jilid III. (Kairo: al-Maktabah alSalafiyah), 409.
} 
haram pernikahannya, dengan lelaki yang tidak beragama Islam, sebelum mengungkap dali-dalil dari hadis nabi.

Secara historis tidak satupun agama yang membolehkan nikah beda agama, maka menurut hemat penulis yang terpenting adalah bagaimana setiap agama memberikan dalil agama masingmasing dengan jujur. Sehingga tidak terjadi ketimpangan penafsiran, seperti yang terjadi pada MUI dan kalangan ilmuwan progresif semisal Nur Cholish masjid dkk.

\section{Aspek Kesetaraan Jender}

Dalam pembahasan hukum Islam, khususnya dalam literatur hukum Islam klasik, Perkawinan Beda Agama dapat dibedakan menjadi tiga kategori: Pertama, Perkawinan antara seorang pria muslim dengan seorang wanita musyrik; Kedua, Perkawinan antara seorang pria muslim dengan wanita ahli kitab; dan Ketiga, Perkawinan antara seorang wanita muslimah dengan pria non muslim (sama adanya musyrik atau ahli kitab) ${ }^{50}$

Terkait dengan hasil penelitian yang menemukan fakta bahwa perkawinan laki-laki muslim dengan wanita non muslim menghasilkan 50\% anak beragama Islam. Sementara perkawinan laki-laki non muslim dengan wanita muslim menghasilkan 77$79 \%$ beragama Islam. Hasil penelitian tersebut tidak sepenuhnya benar, karena pendidikan pasangan yang melakukan perkawinan beda agama $50 \%$ lebih dilakukan oleh orang desa yang pendidikannya rendah (bahkan ada yang tidak tamat SD) hasil penelitian lain menyebutkan bahwa rendahnya tingkat keagamaan suami atau istri menyebabkan persoalan agama di antara mereka bukan merupakan prioritas yang utama, karena kebahagiaan dalam kehidupan rumah tangga bagi perkawinan beda agama adalah terpenuhinya kewajiban suami istri, yang diukur dari kebutuhan, ekonomi, psikologis dan spritual. ${ }^{51}$ Dalam penelitian tersebut juga ditemukan bahwa setelah berumah

${ }^{50}$ Masjfuk Zuhdi, Masail Fiqhiyah (Jakarta, Gunung Agung, 1994), 4.

${ }^{51}$ Ermi Suhasti, "Harmoni Keluarga Beda Agama di Mlati Sleman," Jurnal Ilmu Syariah, Vol. 45, No. 1, (2011): 48. 
tangga, salah satu pasangan yang tingkat keagamaannya semula rendah akan semakin rendah, mereka hanya mengikuti hanya mengikuti ibadah yang bersifat tradisi (syawalan dan natal) tanpa melakukan ibadah-ibadah yang bersifat ritual, sehingga tingkat keagamaan tersebut berpengaruh kepada anak-anaknya dan mereka akan memilih agama salah satu orang tua yang di pandang lebih kuat. ${ }^{52}$

Secara garis besar MUI konsisten dalam menerapkan syariat yang telah dirumuskan oleh para ulama terdahulu, keputusannya dalam persoalan pernikahan beda agama terkesan responsif terhadap kesetaraan. Terlihat dari keputusanya menetapkan bahwa laki-laki dan perempuan muslim tidak dibenarkan menikah dengan lintas agama dan hukumnya haram. Akan tetapi pada sisi lain MUI menampilkan sifatnya yang subordinatif. Hal itu terlihat ketika MUI mengemukakan hadis yang bersifat anjuran pernikahan bagi laki-laki, dan tidak menampilkan hadis lain semisal yang merupakan ketentuan bagi perempuan.

Pada dasarnya rujukan-rujukan yang disandarkan pada ulama klasis sangat otoritatif di masanya, karena pada saat itu masyarakatnya didominasi patriarkhi. Sehingga fatwa-fatwa semisal yang melegitimasi perempuan sebagai masyarakat kelas dua, diterima dengan begitu saja karena perempuan sendiri menerima hal itu. Contohnya, persoalan wanita harus berdoa atau melakukan salat di suatu tempat yang paling tersembunyi, tidak tampak oleh pandangan. Wanita harus menyerahkan seluruh jiwa raganya kepada suami kapan pun suami menghendakinya, atau keselamatan wanita sangat bergantung pada kepuasan atau keinginan suami, atau wanita akan mengisi sebagian besar tempat yang tersedia bagi penduduk neraka. ${ }^{53}$ Kesemuanya itu dianggap oleh Khalid sebagai tindakan ofensif-apresif dan merendahkan wanita yang tidak berdasar secara moral. Itu semua merupakan

\footnotetext{
${ }^{52}$ Ermi Suhasti, "Harmoni Keluarga Beda Agama di Mlati Sleman," Jurnal Ilmu Syariah, Vol. 45, No. 1, (2011): 49.

${ }^{53}$ Khalid M. Abou El Fadl, Atas Nama Tuhan, 301-384.
} 
wujud nyata bagi interpretasi diskriminatif terhadap teks-teks agama.

Dalam bukunya yang berjudul The Great Theft Wrestling Islam from the Extremists, yang diterjemahkan oleh Helmi Mustafa dengan judul Selamatkan Islam dari Muslim Puritan, Khalid menguraikan pandangan dan perilaku agresif patriarkhi dengan memanfaatkan sejumlah konsep teologis. Ia juga menjelaskan sebuah insiden yang terjadi di Mekah sekitar pertengahan Maret 2002, yang minimal empat belas gadis muda terbakar dalam kebakaran yang melanda sekolah mereka, hanya lantaran polisi agama Saudi (Mutatowwa'un) mencegah gadisgadis itu keluar gedung dan menghalangi petugas pemadam kebakaran memasuki gedung tersebut karena gadis-gadis itu tidak tertutup dengan baik. ${ }^{54}$

\section{HADIS TENTANG KEPEMIMPINAN PEREMPUAN}

Majelis Ulama Indonesia pusat secara struktural formal belum pernah meluncurkan fatwa tentang kepemimpinan perempuan, hanya sebatas bentuk komentar singkat terkait dengan fatwa yang diluncurkan oleh MUI daerah. Di antaranya Majelis Ulama Indonesia (MUI) Provinsi Riau pada tahun 2011 mengecam perempuan menjadi calon Wali Kota Pekanbaru. Menurut mereka, pencalonan perempuan tak sesuai dengan ajaran Islam. Itu ditegaskan anggota Komisi Ukhwah MUI Riau, Muhammadun. Menurutnya, perempuan haram mencalonkan diri apabila masih ada laki-laki yang bisa menjadi pemimpin suatu negeri. Ia pun meminta perempuan Riau tak meramaikan bursa kepala daerah. ${ }^{55}$ Pada tahun 2004 beberapa ulama Jawa timur juga berfatwa tentang keharaman presiden perempuan. kemudian Majelis Ulama Indonesia Pusat yang diwakili oleh Din Samsuddin menyatakan diri tidak perlu menanggapi fatwa yang dilontarkan oleh beberapa ulama Jawa timur karena hal itu tidak

\footnotetext{
${ }^{54}$ Khalid Abou El Fadl, Selamatkan Islam dari Muslim Puritan, Terj. Helmi Mustofa (Jakarta: PT Serambi Alam Semesta, 2006), 300-302.

${ }^{55}$ www.metrotvnews.com
} 
akan mempengaruhi masyarakat. menurutnya persoalan kepemimpinan perempuan sebenarnya sejak Oktober 1999 ketika dilaksanakan Kongres Umat Islam pernah diminta fatwa tentang kepemimpinan perempuan, namun hingga kini tidak pernah dibahas oleh Komisi Fatwa MUI.

1. Aspek Hadis

$$
\begin{aligned}
& \text { حدثنا عثمان بن المثيم حدثنا عوف عن الحسن عن أبي بكرة قال: "لقد نِّعني الله بكلمة سمعتها من }
\end{aligned}
$$

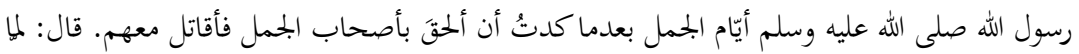

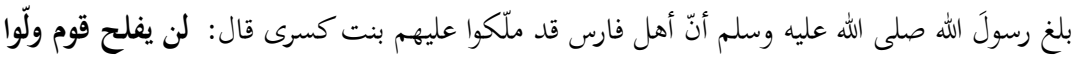

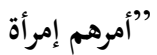

“Ketika sampai kepada Nabi berita tentang bangsa Persia yang mengangkat anak perempuan Kisra sebagai Ratu mereka, Nabi bersabda: "Tidak akan bahagia suatu kaum yang menyerahkan urusan mereka kepada perempuan." 56

Hadis di atas dapat ditemukan di beberapa kitab hadis (Bukhari, tirmidhi, al-Nasai, dan Ahmad Ibn Hanbal), untuk menelusuri kesahihan sanadnya cukup mengambil dua hadis sebagai sampel, yang diriwayatkan masing-masing oleh Bukhari dan Ahmad bin Hanbal.

Hadis ini cukup kontroversial, hadis ini diriwayatkan oleh Abi Bakra, sesuai dengan penelusuran Fatimah mernisi bahwa Abi bakra adalah seorang budak. Oleh karena itu, ia sulit dilacak silsilahnya. Dalam tradisi kesukuan dan aristokrasi Arab, apabila seseorang tidak memiliki sislsilah yang jelas, maka secara sosial tidak diakui statusnya. Bahkan, Imam Ahmad yang melakukan penelitian biografi para sahabat mengakui telah melewatkan

\footnotetext{
${ }^{56}$ Program CD, Mausu'ah al-Hadis Syarif, Sahih Bukhari, No hadis: 4073,
} $6570,2188,5293$. 
begitu saja Abu Bakrah dan tidak menyelidikinya secara lebih mendetail. $^{57}$

Mengutip dari Fatimah Mernisi dan Khaled Abou El-Fadl terhadap sejarah kehidupan Abi Bakrah cukup mengejutkan. Abi Bakrah dituduh sebagai penyebar fitnah dan Umar bin Khattab menolak kesaksiannya dalam kasus-kasus hukum. Ini lantaran ia menuduh al-Mughirah bin Syu'bah, seorang Gubernur Basrah masa kekhalifahan Umar, yang dilihatnya sering mengunjungi seorang perempuan yang sudah bersuami, yaitu Ummi Jamil bint Amir. Abi Bakrah bersama beberapa saudara tirinya menyaksikan al-Mughirah dan Ummi Jamil tidak berpakaian dan terlibat dalam akivitas seksual. Keputusannya, Abi Bakrah dan beberapa saudaranya itu dijatuhi hukum cambuk, dan setelah itu dua orang saudara Abi Bakrah, Ziyad dan Nafi', bertobat dan menarik tuduhannya, sementara Abi Bakrah tetap kokoh dengan tuduhannya sehingga kesaksiannya dalam persoalan-persoalan hukum tidak diterima lagi pasca kejadian ini. ${ }^{58}$

Hadis ini merupakan hadis yang paling sering dijadikan sandaran hukum untuk melegitimasi hukum perempuan menjadi pemimpin di ruang publik. Pada prinsipnya, hadis merupakan representasi dan produk budaya pada masa nabi. jadi sudah barang tentu sangat berkaitan dengan sosial budaya pada saat itu, maka untuk memahami hadis ini secara komprehensif perlu ditelusuri keadaan yang berkembang pada saat hadis itu disabdakan, atau latar belakang munculnya hadis dan setting sosial pada saat itu. Oleh sebab itu untuk memahami makna dari kandungan hadis tersebut mutlak diperlukan informasi yang memadai tentang latar belakang kejadiannya.

Jauh sebelum hadis itu muncul, Rasulullah telah mengutus Abdullah Ibn Hudhafah al-Sami untuk mengirimkan surat tersebut kepada pembesar Bahrain. Kemudian pembesar Bahrain

\footnotetext{
${ }^{57}$ Fatima Mernissi. Women and Islam: An Historical and Theological Enquiry, terj. Yaziar Radianti, (Bandung: Pustaka, 1991), 54.

${ }^{58}$ Khaled M.Abou El Fadl, Atas Nama Tuhan; Dari Fikih Otoriter ke Fikih Otoritatif, terj. R. Cecep Lukman Yasin (Cet.I; Jakarta: Serambi, 2004), 168.
} 
tersebut memberikan surat kepada kisra. Setelah menerima surat nabi tersebut kisra menolak bahkan merobek-robek surat nabi itu. Menurut riwayat Ibn Musayyab, setelah peristiwa tersebut sampai kepada nabi kemudian Rasulullah bersabda "siapa saja yang telah merobek-robek suratku, dirobek-robek (diri dan kerajaan) orang itu. ${ }^{59}$

Di kemudian hari, kerajaan Persia dilanda kekacauan dan terjadi pembunuhan yang dilakukan oleh keluarga dekat raja. Kemudian diangkatlah seorang perempuan yang bernama Buwaran binti Shairawaih bin kisra (cucu kisra yang pernah dikirimi surat oleh nabi) sebagai ratu (kisra) di Persia, setelah terjadi pembunuhan-pembunuhan dalam rangka suksesi kepemimpinan. Jatuhnya pilihan kepada dirinya sebagai ratu karena ayah Buwaran meninggal dunia dan anak laki-lakinya (saudara Buwaran) telah mati terbunuh ketika melakukan perebutan kekuasaan. Maka Buwaran dinobatkan menjadi ratu. ${ }^{60}$

Seandainya otentisitas sebuah hadis dapat dibuktikan, tidakserta merta kemudian dapat membuktikan kebenarannya. Karena yangakan dilihat kemudian adalah peran apa yang dimainkan Nabi dalamriwayat tersebut. Kompetensi menurut Abou El Fadl-tidak hanyamerujuk pada keputusan tentang otentisitas sebuah hadis, tetapi jugapada keseluruhan kondisi yang memengaruhi keberwenangan hadis.Penelitian otentisitas tetap perlu dilakukan, tetapi yang jauh lebih penting adalah menguji dan menilai keseluruhan proses kepenga-rangan dan mencapai sebuah keputusan tentang bagaimana dan sejauhmana beragam suara pengarang membentuk dan membentuk ulangsuara pengarang historis (Nabi dan Sahabat). Menurut Abou el-Fadl,Nabi adalah manusia biasa yang berbeda dengan Tuhan, tunduk padaproses sejarah dunia, maka warisannya tidak dapat diletakkan di luarkonteks campur tangan dan proses keperangan manusia. Autentisitasdan kemurnian Nabi, dari

${ }^{59}$ Ibn Hajar al-Asqalani, Fath al-Bari (Beirut: Dar al-Fikr, t.t.), 127-128.

${ }^{60}$ Abu Falah Abd al-Hayy Ibn al-'Imad al-Hanbali, shazarat al-dhahab Fì al-Akhbar man dhahab (Beirut: Dar al-Fikr, 1979), 1, 13. 
sudut pandang teologis Islam, jelas adalahunsur manusiawinya. Nabi tidak berinteraksi dengan sejarah sebagaiTuhan, tapi sebagai bagian dari dinamika kehidupan manusia yangnormal. Ini jelas berarti bahwa perintah moral dan normatif Nabimuncul dalam sebuah konteks sejarah. Pesan moral Nabi disajikan dandiuji oleh konteks historisnya, tetapi konteks tersebut tidak dapat dantidak menampung seluruh kebenaran dan kenyataan pengalaman moral Nabi. ${ }^{61}$

\section{Aspek Kesetaraan Jender}

Dalam konteks dunia modern, ada Indira Gandi, MargaretTacher, Srimavo Bandahanaeke, Benazir Butho, dan SyekhHasina Zia yang dikenal sebagai pemimpin perempuan sukses.Dan fakta membuktikan, banyak pemimpin laki-laki yang gagal.Jadi, kesuksesan dan kegagalan menjadi seorang bukan karenajenis kelamin, tetapi karena integritas dan kapabilitasnya. ${ }^{62}$

Penafsiran yang diberikan kepada biologis perempuan menyebabkan kerugian mereka pada semua tingkat masyarakat bukan keadaan biologis mereka sendiri. Perempuan di manapun umumnya kurang dikenal dan kurang berwenang dalam adat. Penafsiran inilah yang mengikat mereka untuk hanya mengasuh anak-anak dan tetap dalam lingkungan rumah tangga. ${ }^{63}$

Tafsiran terhadap teks agama sangat berperanan penting dalam membenarkan dominasi terhadap kaum wanita. Persoalannya, mengapa al-Quran menempatkan kedudukan lelaki di atas wanita? Dalam memahami ayat "al-Rijalu Qawwamuna 'Ala al-Nisa" hendaklah diuraikan sebagai deskripsi keadaan struktur dan norma sosial masyarakat pada masa itu, dan

\footnotetext{
${ }^{61}$ Khaled M.Abou El Fadl, Atas Nama Tuhan; Dari Fikih Otoriter ke Fikih Otoritatif, 163.

${ }^{62}$ Husein Muhammad, Fiqh Perempuan: Refleksi Kiai atas Wacana Agama dan Gender(Yogyakarta: LKiS, 2012), cet. ke-6, 195-203.

${ }^{63}$ Arief Budiman, Pembahagian Kerja Secara Seksual: Sebuah Perbahasan Sosiologis Tentang Peran Wanita di Dalam Masyarakat (Jakarta: PT Gramedia, 1982), 2.
} 
bukanlah suatu norma ajaran yang harus dipraktikkan. ${ }^{64}$ Selain itu, timbul isu hak kahwin wanita dinombor duakan, bahagian waris wanita lebih kecil, wanita perlu mahram ketika bermusafir, wanita muslimah tidak boleh berkahwin dengan lelaki bukan Islam, ${ }^{65}$ wanita tidak boleh menjadi imam solat lelaki, tidak boleh azan, tidak wajib solat jumaat berbanding lelaki, wanita muda dilarang ke masjid dan wanita perlu menutup aurat seluruh badan. Persoalan tersebut perlu dikaji lebih dalam secara sosio historis, melihat kembali bagaimana konteks ayat-ayat yang berkaitan dengan persoalan yang dianggap bersifat subordinatif tersebut. Jika tidak maka seorang penafsir akan terjebak pada kesalahpahaman kandundungan makna teks.

Dengan ketat melalui berbagai jalur legislatif, politik maupun budaya, perkembangan gerakan perempuan diarahkan menuju satu titik yaitu domestikasi perempuan, dengan meletakkan perempuan di dalam rumah tangga, sebagai misteri pendamping suami dan ibu dari anak-anaknya. ${ }^{66}$ Kebijakan ini menjadikan perempuan bersikap apolitis atau rendah kesadaran politiknya.

Musda Mulya mengemukakan bahwa masih kuatnya pandangan-pandangan bahwa perempuan lebih cocok dengan pekerjaan-pekerjaan rumah tangga dibanding laki-laki, atau pandangan bahwa perempuan lebih menggunakan perasaannya dari pada rasional, sehingga perempuan tidak cocok dengan bidang-bidang pekerjaan yang keras dan rasional termasuk bidang politik yang dianggap hanya cocok dengan laki-laki. Ini

\footnotetext{
${ }^{64}$ Kaukab Siddique, The Struggle of Muslim Women, terj. Arif Maftuhin, Menggugat Tuhan yang Maskulin, Jakarta: Paramadina, 2002), 11-13; Mansour Fakih, "Posisi Kaum Perempuan Dalam Islam: Tinjauan Dari Analisis Gender", Membincang Feminisme: Diskursus Gender Perspektif Islam, ed. ke-2 (Surabaya: Risalah Gusti, 2000), 53.

${ }^{65}$ Mun'im Sirry, ed., Fiqih Lintas Agama: Membangun Masyarakat Inklusif-Pluralis, cet. 7(Jakarta: Paramadina, 2005), 164.

${ }^{66}$ Mansour Fakih, Analisis Gender dan Transformasi Sosial, cet. 2 (Yogyakarta: Pustaka Pelajar, 2007), 74.
} 
merupakan gambaran mengenai adanya diskriminasi klasik terhadap perempuan. ${ }^{67}$

Cita-cita al-Qur'an adalah terciptanya sebuah kehidupan manusia yang bermoral yang menghargai nilai-nilai kemanusiaan universal. Al-Qur'an misalnya menyatakan: Hai manusia, Kami telah menciptakan kamu dari laki-laki dan perempuan, dan kami telah jadikan kamu berbangsa-bangsa dan bersuku-suku supaya kamu saling mengenal. Sesungguhnya yang paling mulia di antara kamu di sisi Allah adalah yang paling takwa. (QS: alHujurat: 13) Dalam konteks fikih bahwa syariat Islam dibangun untuk kepentingan manusia dan tujuan-tujuan kemanusiaan universal yang lain, yaitu kemaslahatan, keadilan, kerahmatan dan kebijaksanaan. ${ }^{68}$

Mereka sepakat bahwa kemaslahatan merupakan basis dan tujuan utama syari'ah Islam. Secara lebih khusus, al-Ghazali dengan sangat mengesankan telah merumuskan kemaslahatan ini dalam bukunya yang terkenal al-Mustasfa min 'ilmu al-Ushul. Ia mengatakan: Kemaslahatan menurut saya adalah mewujudkan tujuan-tujuan agama, yaitu menjaga lima hal: agama (hifzh alnasl), jiwa (hifzh al-nafs), akal (hifzh al-aql), keturunan (hifzh alnasl), dan harta benda (hifzh al-mal). ${ }^{69}$ Setiap hal yang mengandung perlindungan terhadap lima prinsip ini adalah kemashlahatan, dan setiap yang mengasikannya adalah kerusakan (mafsadah), menolak kerusakan adalah kemaslahatan. ${ }^{70}$

${ }^{67}$ Musdah Mulia, Membangun Surga di Bumi: Kiat-kiat Membina Keluarga Ideal dalam

Islam,

${ }^{68}$ Huzaemah T Yanggo, Fikih Perempuan Kontemporer, (al-Mawardi Prima: Jakarta, November 2001), 2.

${ }^{69}$ al- Ghazali, Abu Hamid Muhammad bin Muhammad. al-Mustasfa min 'Ilm al-Usul (Madinah: Shirkah al-Madinah al-Munawwarah, t.t.). lihat juga Jamal Ma'mur Asmani, Kepemimpinan Perempuan: Pergulatan Wacana Di Nahdlatul Ulama (Nu), ADDIN, Vol. 9, No. 1, (Februari 2015), 39.

${ }^{70}$ Lihat Husein Muhammad, membongkar Konsepsi Fikih Tentang Perempuan, dalam buku Kepemimpinan Perempuan Dalam Islam, (Jakarta : JPPR, 1999), 37. 
Syariat Islam sejak kemunculannya telah berusaha mewujudkan keadilan jender dalam masyarakat Arab yang memiliki budaya dan tradisi patriarkhi yang sangat kuat. Upaya tersebut diwujudkan dengan adanya aturan dan doktrin-doktrin yang berusaha mengangkat harkat dan martabat kaum perempuan dari posisinya semula. Aturan-aturan syariat tersebut antara lain mengecam penguburan anak perempuan, membatasi poligami, memberikan hak waris, hak-hak sebagai istri, hak sebagai saksi dan hak-hak lainnya. Dengan kata lain syariat Islam sejak semula telah memberikan hak dan peran kepada kaum perempuan baik di wilayah domestik maupun publik. ${ }^{71}$

\section{KESIMPULAN}

Penelitian ini mendalami dan menelusuri hadis-hadis yang dijadikan sandaran oleh MUI. Di antaranya ada empat kasus, yaitu tentang Pemimpin perempuan dalam ibadah, khitan perempuan, pernikahan beda agama, dan pemimpin perempuan dalam konstitusi. Dan sekaligus menguji hubungan substansi fatwa-fatwa MUI tentang kasus-kasus yang disebutkan di atas dengan konstruksi kesetaraan jender. Penelitian terhadap hadis-hadis yang dijadikan sebagai sandaran MUI dalam mengeluarkan fatwa tentang hal yang disebut di atas menemukan dua kesimpulan, sebagai berikut:

1. Keputusan-keputusan MUI terkait dengan persoalan kesetaraan jender cenderung preventif terhadapa ajaran sunni yaitu kaidahkaidah kesahihan hadis menurut ulama suni. Kecenderungan MUI ini terlihat dari keputusan-keputusannya dalam persoalan perempuan kurang terbuka dengan perkembangan dan kemajuan zaman khususnya dalam lingkup kemampuan dan kualitas perempuan. Meskipun tidak dapat dipungkiri bahwa MUI telah

${ }^{71}$ Nur Mahmudah, Pasang Surut Peran Perempuan Dalam Periwayatan Hadis, PALASTREN, Vol. 7, No. 1, (Juni 2014), 190-191. 
berusaha menempuh proses moderasi. Dengan demikian, untuk menerbitkan sebuah fatwa tentang kesetaraan jender, MUI cukup melihat dan menyesuaikan persoalan tersebut dengan ajaran dan kandungan sunnah, disertai dengan konsensus para ulama (ijma') sebagai dalil penguat dan pendukung atas argumen MUI. Hal ini berbeda dengan argumen fatwa MUI dalam bidang lainnya. Misalnya fatwa dalam bidang muamalah dan sosial-budaya, argumen hukum Islam MUI selain mengutip langsung al-Qur'an dan sunnah, juga menggunakan kaidahkaidah fikih dan metode-metode ushul fikih lainnya. Temuan ini telah sesuai dengan apa yang ditegaskan dalam Pedoman dan Prosedur Penetapan Fatwa MUI, bahwa dalam masalah yang tidak ditemukan pendapat hukumnya di kalangan mazhab, maka penetapan fatwa harus didasarkan pada hasil ijtihad kolektif (jama'i) melalui metode bayani, ta'lili (qiyas, istihsan, ilhaq), istislah, dan sadd al-dhari'ah. Ijma' tersebut menekankan pada penafsiran-penafsiran ulama Sunni. Bagi MUI (dan mayoritas muslim Indonesia), penafsiran-penafsiran ulama-ulama klasik Sunni, seperti kitab Jami' al-Bayan 'an Ta'wil al-Qur'an karya Abi Ja'far Muhammad bin Jarir al-Tabari, Tafsir al-Qur'a $n$ alKarim karya Ibn Kathir al- Dimshaqi, al-Jami` li-Ahkam alQur'an karya Abi 'Abd Allah al- Qurtubi, dan kitab tafsir lainnya, dianggap sebagai pendapat yang otoritatif (mu'tabar) dalam diskursus hukum Islam, maka tidak mengherankan apabila standar penafsiran teks keagamaan MUI dalam setiap fatwanya selalu didasarkan kepada penafsiran-penafsiran ulama klasik tersebut. Hal ini sesuai dengan Pedoman dan Prosedur Penetapan Fatwa MUI yang menegaskan bahwa sebelum fatwa ditetapkan, hendaklah ditinjau lebih dahulu pendapat para imam mazhab dan ulama yang mu'tabar atau otoritatif tentang masalah yang akan difatwakan tersebut.

2. Pada persoalan ini, MUI terkesan kurang selektif dalam menyandarkan argumennya pada hadis nabi. Dalam persoalan 
pernikahan beda agama contohnya, MUI menggunakan hadis yang bermakna umum bahkan hadis tersebut cenderung bermakna anjuran bagi laki-laki yang hendak menikah (hadis buat laki-laki), dengan demikian MUI sejak awal sudah melegitimasi keharaman perempuan muslim untuk menikah dengan laki-laki non muslim, Tampa melacak dalil-dalil hadis yang berkaitan. Padahal ada hadis yang lebih spesifik membahas tentang ketidak bolehan perempuan muslim menikah dengan orang musyrik. Begitu juga dengan persoalan imam salat perempuan, pemimpin perempuan, dan khitan perempuan, Majelis Ulama Indonesia pat diapresiasi dengan sifatnya yang menjaga dan mempertahankan syariat Islam, namun pada sisi lain MUI cenderung memandang persoalan kesetaraan secara parsial, di dalam al-Qur'an dan hadis nabi banyak diterangkan tentang kesetaraan manusia baik secara eksplisit maupun secara implisit. MUI dalam kasus-kasus ini, lebih besar didorong dan dipicu oleh sifatnya yang ingin melakukan perlawanan terhadap pemikir-pemikir progresif. Sehingga MUI terkesan tidak terbuka dengan perkembangan pemahaman teks yang ada. Akan tetapi, pada persoalan muamalah, Syariah perbankan, dan label produk halal haram sangat membuka diri.

\section{DAFTAR PUSTAKA}

Abdullah, Irwan. Sangkan Paran Gender. Cet.ke-1. Yokyakarta: Pustaka Pelajar, 2003

Abdullah, M. Amin. "Pengantar" dalam Khalid M. Abou El Fadl, Atas Nama Tuhan, Terj. Cecep Lukman Yasin, Jakarta: PT Serambi Ilmu Semesta, 2004.

Abdurrahman, Moeslim. Islam sebagai Kritik Sosial, Jakarta: Erlangga, 2003 
Amin, Qasim. Tahrir al-Mar'ah,Mesir: al-Markaz al-'Arabi li alBahth wa al-Nashr, 1948

Amir Piliang,Yasraf.Dunia yang Dilipat: Tamasya Melampaui Batas-batas Kebudayaan, Yogyakarta: Jalasutra, 2004

Amstrong, Karen.Sejarah Tuhan, Cet. ke-2; Bandung: Mizan, 2007

Al-Athir,Ibn.Jami' al-Ushul, juz V, tth

Aziz,Abdul.ikhtilaf al-Darin wa atharuh fi ahkam alShari'ah,Madinah Munawwarah: t.p, 2004

Azra, Azumardi. Jaringan Ulama Timur Tengah dan kepulauan Nusantara Abad XVII dan XVIII: Melacak Akar-akar Pembaharuan Pemikiran Islam di Indonesia. Bandung: Mizan, 1998

Baqir al-Majlisy, Muhammad. Bihar al-Anwar al-Jami'ah Lidurori Akhbari al-A 'imaat al-Athar,Libanon: Mu' asasah al-Wafa'

Budiman,Arief.Pembahagian Kerja Secara Seksual: Sebuah Perbahasan Sosiologis Tentang Peran Wanita di Dalam Masyarakat,Jakarta: PT Gramedia, 1982

Al-Bukhari. 1400 H. Jami' al-Shahih. Jilid III. Kairo: al-Maktabah al-Salafiyah

Cholis Majid,Nur.Fikih Lintas Agama : Membangun Masyarakat Yang Inklusif, Pluralis, Jakarta: Paramadina, 2004

Connoly, Peter.Aneka Pendekatan Studi Agama,Yogyakarta: LKIS Yokyakarta, 2002

Dewi,Ernita. "Pemikiran Amina Wadud Tentang Rekonstruksi Penafsiran Berbasis Metode Hermeneutika," Jurnal Substantia Vol. 15, No. 2, (Oktober 2013)

Fakih,Mansour. "Posisi Kaum Perempuan Dalam Islam: Tinjauan Dari Analisis Gender", Membincang Feminisme: Diskursus Gender Perspektif Islam, ed. ke-2 (Surabaya: Risalah Gusti, 2000) 
Analisis Gender dan Transformasi Sosial, cet. 2

Yogyakarta: Pustaka Pelajar, 2007

Falah Abd al-Hayy Ibn al-'Imad al-Hanbali,Abu.shazarat al-dhahab

Fi al-Akhbar man dhahab,Beirut: Dar al-Fikr, 1979

Al- Ghazali, Abu Hamid Muhammad bin Muhammad. al-Mustasfa min 'Ilm al-Usul,Madinah: Shirkah al-Madinah alMunawwarah, t.t.

Hajar al-Asqalani,Ibn.Fath al-Bari,Beirut: Dar al-Fikr, t.t.

Hidayat, Komaruddin. Memahami Bahasa Agama, Jakarta: Paramadina, 1995

Ibn Anas,Malik.Al-Muwattha'. Jilid II. Beirut: Dar Ihya' al-Turath al-'Arabi. Cet. I, 1424/2003

Ibn Isma'il al-San'ani, Muhammad.Subul al-Salam, ditahqiq oleh Abd al-Aziz Hawli, Beirut: Dar Ihya' al-Turath al-'Arabi, $1379 \mathrm{H}$

Ibn Qudamah, Muhammad.al-Mughni (Cairo: Dar al-Hadis, t.th), juz I, 413-414.

Ilyas, Hamim dkk.Perempuan Tertindas "Kajian Hadis-hadis Misoginis",Jakarta: The Ford Foundation, 2003

Ismail, Syuhudi.Hadis Nabi Yang Tekstual dan Kontekstual, Jakarta: Bulan Bintang, 2009

Jamil,Asrianti. Kajian Tekstual dan Kontekstual tentang Khitan Perempuan dalam Islam Serta Pelaksanaannya, Jakarta: Program Pasca Sarjana UI 2001

Kutha Ratna, Nyoman. Teori, Metode, dan Teknik Penelitian Sastra, Yogyakarta: Pustaka Pelajar, 2006 Yasraf Amir Piliang, Hipersemiotika, Tafsir Cultural Studies Atas Matinya MaknaYogyakarta: Jalasutra, 2003

Levy, Reuben. The Sosial Structure of Islam, Terj. H. Ahmad Ludjito: "Susunan Masyarakat Islam",Jakarta : Pustaka Firdaus, 1986 
M.Abou el-Fadl,Khaled.Atas Nama Tuhan; Dari Fikih Otoriter ke Fikih Otoritatif, terj. R. Cecep Lukman Yasin,Cet.I; Jakarta: Serambi, 2004

M. Abou el-Fadl,Khalid.Selamatkan Islam dari Muslim Puritan, Terj. Helmi Mustofa (Jakarta: PT Serambi Alam Semesta, 2006)

Ma'mur, Jamal. Rezim Gender di NU, 2016

Majlis Ulama Indonesia, Himpunan Fatwa MUI Sejak 1975(Jakarta, 2011), 477-481.

Mernissi dan Riffat Hassan,Fatimah.Setara di Hadapan Allah, Reflasi Laki-laki dan Perempauan dalam Tradisi Islam Pasca Patriarki

Muhammad,Husein.Fiqh Perempuan: Refleksi Kiai atas Wacana Agama dan Gender, Yogyakarta: LKiS, 2012

---------------------.membongkar Konsepsi Fikih Tentang Perempuan, dalam buku Kepemimpinan Perempuan Dalam Islam, Jakarta : JPPR, 1999

Mukhlis Zakariyah, Nur. "Kegelisahan Intelektual Seorang Feminis,"Telaah Pemikiran Fatima Mernissi Tentang Hermeneutika Hadith KARSA, Vol. 19 No. 2 (Tahun 2011):

Mulia,Musdah. Membangun Surga di Bumi: Kiat-kiat Membina Keluarga Ideal dalamIslam,

Program CD, Mausu'ah al-Hadis Syarif

Putnam Tong, Rosemarie. Feminist Thought, Terj. Aquarini Priyatna Prabasmoro, Yogyakarta \& Bandung: Jalasutra, 2006

Al-Qardawi, Yusuf. Kayfa Nata'amal ma'a al-Sunnah alNabawiyah.al-Mansurah:Dar al-Wafa'1990.

Qayyim al-Jauziyyah,Ibn.Tuhfah al-Maududi bi Ahkam al-Maudud, terj. Fauzi Bahreisy, Mengantar Balita Menuju Dewasa, Jakarta: Serambi, 2001 
104 Rausyan Fikr, Vol. 12 No.1Juni 2016: 57-104

Ritzer, George. Teori Sosial Postmodern, Yogyakarta: Kreasi Wacana, 2004

Rusyd, Ibn.Bidaayah al-Mujtahid,Oman: Bayt al-Afkar al-Dawliyah, 2007

Sabiq, Sayyid. Fiqh al-Sunnah, Beirut: Dar al-Fikr, 1983

Shaltut, Mahmud. al-Islam 'Aqidah wa al-Shari'ah, Cairo: Dar alQalam, 1966

Shihab,Quraish.Era Baru Fatwa Baru, pengantar. Jakarta: Teraju, 2003

Siddique,Kaukab.The Struggle of Muslim Women, terj. Arif Maftuhin, Menggugat Tuhan yang Maskulin, Jakarta: Paramadina, 2002

Sirry,Mun'im ed., Fiqih Lintas Agama: Membangun Masyarakat Inklusif-Pluralis, cet. 7Jakarta: Paramadina, 2005

Subhan, Zaitunah. al-Quran dan Perempuan,Jakarta: Prenadamedia Group, 2015

Sulayman al-NuIr dan Alwi 'Abbas al-Maliki, Hasan. Ibanat alAhkam Sharh Bulug al-MaramBeirut: Dar al-Thaqafah alIslamiyah, 1960

T Yanggo,Huzaemah.Fikih Perempuan Kontemporer, al-Mawardi Prima: Jakarta, November 2001

Umar, Nasaruddin. Argumen Kesetaraan gender,Jakarta: Paramadina, 1999

Ketika Fikih Membela Perempuan, Jakarta: Gramedia, 2014

Al-Zuhayli, Wahba. al-Fiqh al-Islami wa adillatuhu,Beirut: Dar, 1996

Zuhdi,Masjfuk.Masail Fiqhiyah,Jakarta: Gunung Agung, 1994

\section{Referensi Journal:}


Duderija, Adis. "Toward a Methodology of Understanding the Nature and Scope of the Concept of Sunnah", Arab Law Quarterly, Vol. 21, No. 3, 2007.

Ma'mur, Jamal. Kepemimpinan Perempuan, ADDIN, Vol. 9, No. 1, Februari 2015.

Mahmudah, Nur. Pasang Surut Peran Perempuan Dalam Periwayatan Hadis, PALASTREN, Vol. 7, No. 1, Juni 2014.

Majid, Abdul. Hermeneutika Hadis Gender (Studi Pemikiran Khaled M. Abou El Fadl dalam Buku Speaking in God's Name; Islamic Law, Authority And Women), Jurnal al-Ulum, Volume. 13 Nomor 2, Desember 2013

Matswa, Akrimi. Hermeneutika Negosiatif Khaled Muhammad Abou El Fadl Terhadap Hadis Nabi, Hermeneutik, Vol. 9, No. 1, Januari Juni 2013

Muhammad, Husein. "Kritik Tafsir Gender", salam YinYang. Jurnal Studi Gender, Ibu, dan Anak Purwokerto: PSG STAIN Purwokerto Vol. 1 No. I 2006.

Muhyiddin. "Fatwa MUI Tentang Vasektomi", al-Ahkam, Volume 24, Nomor 1, April 2014.

Nur Ichwan, Moch. "Ulama State and Politics: Majelis Ulama Indonesia after Suharto," Islamic Law and Society 12 (2005).

Nur Ichwan, Moch. Ulama, "State and Politics: Majelis Ulama Indonesia after Suharto", Islamic Law and Society, Vol. 12, No. $1,2005$.

Nurani, Shinta. Implikasi Tafsir Klasik Terhadap Subordinasi Gender: Perempuan Sebagai Makhluk Keduamuwazah, MUAZAH, Volume 7, Nomor 2, Desember 2015.

Nurmila, Nina. Pengaruh Budaya Patriarki Terhadap Pemahaman Agama Dan Pembentukan Budaya KARSA, Vol. 23 No. 1, Juni 2015.

Nursyam. "konsep kesetaraan gender dalam pemikiran Islam", Musawa, Vol. 4, No. 2, Desember 2012.

Rasyid Baswedan, Anies. "Political Islam in Indonesia: Present and Future Trajectory", Asian Survey, Vol. 44, No. 5, September/October 2004.

Sahid. "Revolusi Sunnah", Al-Tahrir, Vol. 11, No. 1 Mei 2011. 
Saifuddin, "Legal Opinion (Fatwa) of MUI (Council of Indonesian Ulama') on Ahmadiyah", al-Zarqa', Vol. 4, No. 2, Desember 2012.

Sayeed, Asma. "Gender and Legal Authority: Islamic Law and Society", Vol. 16, No. 2, 2009.

"Women and Hadith Transmission Two Case Studies from Mamluk Damascus "Studia Islamica, No. 95, 2002.

Sodik, Mochamad. Mencairkan Kebekuan Fiqh: Membaca KHI dan CLD KHI bersama Musda Mulia, Jurnal Ilmu Syariah, Vol. 38, No.II, 2004.

Sofie Roald, Anne. 'Notions Of 'Male' And 'Female' Among Contemporary Muslims: With Special Reference To Islamists", Islamic Studies, Vol. 38, No. 3, Autumn 1999.

Suhasti, Ermi. Harmoni Keluarga Beda Agama di Mlati Sleman, Yogyakarta, Asy-Syir'ah, Jurnal Ilmu Syariah, Vol. 45, No. 1, 2011. 